\title{
26. UPPER CRETACEOUS AND CENOZOIC CALCAREOUS NANNOFOSSILS OF THE KERGUELEN PLATEAU (SOUTHERN INDIAN OCEAN) AND PRYDZ BAY (EAST ANTARCTICA) ${ }^{1}$
}

\author{
Wuchang Wei ${ }^{2}$ and Hans R. Thierstein ${ }^{3}$
}

\begin{abstract}
ODP Leg 119 drilled 11 sites on the Kerguelen Plateau (southern Indian Ocean) and Prydz Bay (East Antarctica). Upper Pliocene through Quaternary sediments were recovered at Site 736 on the northern Kerguelen Plateau; calcareous nannofossils occurred in only a few samples. Over $700 \mathrm{~m}$ of middle Eocene through Quaternary sediments was cored at Site 737 on the northern Kerguelen Plateau, and calcareous nannofossils are abundant in the middle Eocene through the middle Miocene sediments. Nearly $500 \mathrm{~m}$ of sediments ranging from the lower Turonian to the Quaternary was recovered at Site 738 on the southern Kerguelen Plateau; calcareous nannofossils are abundant from the Miocene downward. Calcareous nannofossils are also abundant in the upper Eocene through Miocene section from Site 744 on the southern Kerguelen Plateau. Except for Core 119-746A-13H, the Neogene sequences drilled at deep-water Sites 745 and 746 off the southern Kerguelen Plateau are devoid of calcareous nannofossils. Occurrences of calcareous nannofossils were generally rare and sporadic at Sites 739 and 742 in Prydz Bay and suggest that the diamictite sequences recovered is as old as middle Eocene-early Oligocene age. Other sites drilled in Prydz Bay (Sites 740, 741, and 743) did not yield calcareous nannofossils.

Species diversity of calcareous nannofossils was low (about a dozen) in the southern Indian Ocean in the Late Cretaceous. High-latitude nannofloral characteristics are apparent after the Cretaceous/Tertiary boundary extinctions. Cold climatic conditions limited Oligocene calcareous nannofossil assemblages to fewer than a dozen species, and extinctions of species generally were not compensated by originations of new species. Only a few species of calcareous nannofossils were found in the Miocene sequences, in which Coccolithus pelagicus and one or two species of Reticulofenestra exhibit extreme $(0 \%-100 \%)$ fluctuations in assemblage dominance, and these fluctuations may reflect rapid fluctuations in the surface-water temperatures. Further deterioration of climate in the late Neogene essentially excluded calcareous nannoplankton from the Southern Ocean. Significantly warmer water conditions during part of the early-middle Pleistocene were inferred by a few lower-middle Pleistocene calcareous nannofossil species found on the Kerguelen Plateau.

The calcareous nannofossil zonation of Roth (1978) can be applied to the Upper Cretaceous section recovered at Site 738 , and the zonation of Okada and Bukry (1980) can be applied without much difficulty to the Paleocene to middle Eocene sequences from the Kerguelen Plateau. However, some conventional upper Paleogene markers are not useful for southern high latitudes, whereas a few nonconventional species events are useful for subdividing the upper Paleogene sequences. The latter species events include the first occurrence (FO) of Reticulofenestra reticulata, the FO and last occurrence (LO) of Reticulofenestra oamaruensis, the LO of Isthmolithus recurvus, and the LO of Chiasmolithus altus. As the Neogene sequences from the southern Indian Ocean contain only a few long-ranging, cold-water species, or are devoid of coccoliths, calcareous nannofossil zonations remain virtually unworkable for the Neogene in the high-latitude southern Indian Ocean as in other sectors of the Southern Ocean.
\end{abstract}

\section{INTRODUCTION}

Ocean Drilling Program (ODP) Leg 119 was the first DSDP/ ODP drilling on the world's largest submarine plateau, the Kerguelen Plateau in the southern Indian Ocean, as well as Prydz Bay on the shelf of East Antarctica (Fig. 1). The Kerguelen Plateau, located on the Antarctic plate, extends approximately $2500 \mathrm{~km}$ between $46^{\circ} \mathrm{S}$ and $64^{\circ} \mathrm{S}$ latitude in a northwest-southeast direction. The feature is between 200 and $600 \mathrm{~km}$ wide, and stands $2-4 \mathrm{~km}$ above the adjacent ocean basins. Surface currents over the plateau are dominated by the Antarctic Convergence, or Polar Front, which fluctuates over the plateau and separates subantarctic waters to the north from antarctic waters to the south. A principal objective of drilling in this region during Leg 119 was to provide evidence of the development of the Antarctic Convergence and the response of this oceanographic boundary to climatic change. A second major objective was to

\footnotetext{
${ }^{1}$ Barron, J., Larsen, B., et al., 1991. Proc. ODP, Sci. Results, 119: College Station, TX (Ocean Drilling Program).

2 Department of Geology, Florida State University, Tallahassee, FL 32306, U.S.A.

3 Geological Institute, ETH-Zentrum, CH-8092 Zurich, Switzerland.
}

investigate the origin and tectonic history of the Kerguelen Plateau and the breakup history of the Kerguelen Plateau from Broken Ridge. Prydz Bay is situated on the continental shelf of East Antarctica and drains over $20 \%$ of the East Antarctic ice sheet. Drilling in Prydz Bay was expected to have the best chance of recovering a relatively complete record of Antarctic glaciation and the preglacial continental climate.

A total of 11 sites were drilled during ODP Leg 119 (Table 1). Relatively few calcareous nannofossils were found at Site 736, which recovered only upper Neogene sediments. Significant numbers of calcareous nannofossils were recovered at ODP Sites 737 (middle Eocene to Quaternary), 738 (early Turonian to Quaternary), and 744 (late Eocene to Quaternary), which were continuously cored. Except for one core section from Site 746, Sites 745 and 746 off the Kerguelen Plateau are barren of nannofossils, because of their great water depths (4082 and $4059 \mathrm{~m}$, respectively). Sites 739 and 742 in Prydz Bay yielded only rare and sporadic occurrences of calcareous nannofossils, whereas other sites in Prydz Bay were barren of nannofossils.

This paper documents the calcareous nannofossils recovered during Leg 119 and establishes nannofossil biostratigraphy for the core materials. The stratigraphic sequences of the calcareous nannofossils are important reference sections for the Southern Ocean and will serve as the southern anchor in the Indian 


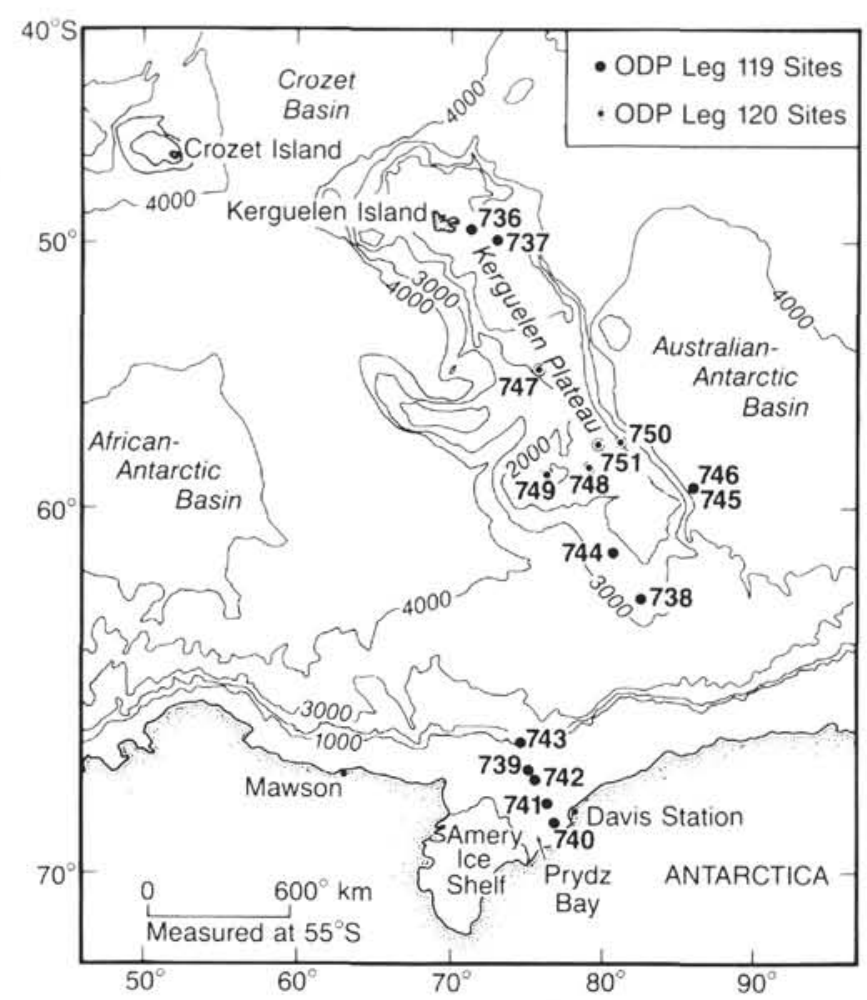

Figure 1. Locations of Ocean Drilling Program Leg 119 sites and subsequently drilled Leg 120 sites. Bathymetry in meters.

Ocean sector of the Southern Ocean for future paleobiogeographic and paleoecologic studies.

Previous biostratigraphic studies of calcareous nannofossils of the high southern latitudes have been published by Edwards (1971, 1973), Edwards and Perch-Nielsen (1975), Burns (1975), Haq (1976), Wind (1979a, b), Wise and Wind (1977), Wise (1983), Pospichal and Wise (1990a, b, c), and Wei and Wise (1990).

Calcareous nannofossil species considered in this paper are listed in the Appendix, where they are arranged alphabetically by generic and species epithets. Most of the species are illustrated in Plates 1 through 6, and the illustrations are cross referenced in the appendix. Most bibliographic references for these taxa can be found in Loeblich and Tappan $(1966,1968,1969$, 1970a, b, 1971, 1973), van Heck (1979a, b, 1980a, b, 1981a, b, 1982a, b, 1983), or Steinmetz (1985a, b, 1986, 1987a, b, 1988a, b, 1989), any not included therein are given in the references.
For Cenozoic biostratigraphy we use the zonation of Okada and Bukry (1980). For the Mesozoic section we apply the zonation of Roth (1978), because many of the biostratigraphic events used there have since been correlated directly to the magnetochronology in various sections (e.g., Stradner and Steinmetz, 1984; Monechi and Thierstein, 1985). However, due to extreme high latitudes, calcareous nannofossils recovered by ODP Leg 119 are relatively low in diversity. The problem is most acute for the Neogene, where the calcareous nannofossil zonation is essentially unworkable. For the middle Eocene through Oligocene, latitudinal differentiation of the nannofossil assemblages are also quite apparent, and some marker species in the zonations of Martini (1971) or Okada and Bukry (1980) are absent or very rare, whereas some cool-water species markers are common and easily used. Therefore, in addition to making zonal assignments according to the zonation of Okada and Bukry (1980), we also adopt the zonation developed in the Weddell Sea by Wei and Wise (1990) for the middle Eocene through Oligocene to facilitate correlation with low-latitude sequences and to achieve a more refined biostratigraphy for Leg 119 cores. The zonation adopted for the middle Eocene through Oligocene interval is summarized in Figure 2, which is a slight modification of Wei and Wise's (1990) zonation with the erection of the last occurrence (LO) of Discoaster saipanensis as a subzonal marker and the use of LO of Reticulofenestra bisecta as a zonal marker.

\section{METHODS AND PROCEDURES}

Smear slides were made directly from unprocessed samples and examined using a light microscope to estimate the relative abundance of calcareous nannofossils in the fine fractions of the sediment and the relative abundance of each nannofossil species present. Usually several hundred fields of view were scanned at a magnification of about $1600 \times$ and the relative species abundances were estimated using the following scale:

$$
\begin{aligned}
\mathrm{V}= & \text { very abundant }(>40 \%) \\
\mathrm{A}= & \text { abundant }(10 \%-40 \%) \\
\mathrm{C}= & \text { common }(1 \%-10 \%) \\
\mathrm{F}= & \text { few }(0.1 \%-1 \%) \\
\mathrm{R}= & \text { rare }(<0.1 \%) \\
\mathrm{B}= & \text { barren (no nannofossils seen in several hundred fields } \\
& \text { of view). }
\end{aligned}
$$

Selected samples were examined using a scanning electron microscope (SEM) to reveal ultrastructural details. A qualitative determination was made on the overall state of preservation of nannofossils in each sample. The following basic criteria were used to describe qualitatively the degree of dissolution and/or overgrowth of a nannofossil assemblage.

Table 1. Summary of sites drilled during Ocean Drilling Program Leg 119.

\begin{tabular}{lcccccl}
\hline Site & Latitude & Longitude & $\begin{array}{c}\text { Water depth } \\
(\mathrm{m})\end{array}$ & $\begin{array}{c}\text { Penetration } \\
(\mathrm{mbsf})\end{array}$ & $\begin{array}{c}\text { Percent } \\
\text { recovery }\end{array}$ & $\begin{array}{c}\text { Oldest } \\
\text { sediment }\end{array}$ \\
\hline 736 & $49^{\circ} 24.121^{\prime} \mathrm{S}$ & $71^{\circ} 39.611^{\prime} \mathrm{E}$ & 629.0 & 371 & 51 & late Pliocene \\
737 & $50^{\circ} 13.660^{\prime} \mathrm{S}$ & $73^{\circ} 01.950^{\prime} \mathrm{E}$ & 564.0 & 715.5 & 63 & middle Eocene \\
738 & $62^{\circ} 42.543^{\prime} \mathrm{S}$ & $82^{\circ} 47.245^{\prime} \mathrm{E}$ & 2252.5 & 534 & 58 & early Turonian \\
739 & $67^{\circ} 16.570^{\prime} \mathrm{S}$ & $75^{\circ} 04.914^{\prime} \mathrm{E}$ & 412.3 & 478 & 35 & ?Eocene \\
740 & $68^{\circ} 41.220^{\prime} \mathrm{S}$ & $76^{\circ} 43.246^{\prime} \mathrm{E}$ & 816.0 & 225.5 & 32 & ?Mesozoic or Permian \\
741 & $68^{\circ} 23.160^{\prime} \mathrm{S}$ & $76^{\circ} 23.020^{\prime} \mathrm{E}$ & 561.4 & 128.1 & 26 & Early Cretaceous \\
742 & $67^{\circ} 32.982^{\prime} \mathrm{S}$ & $75^{\circ} 24.270^{\prime} \mathrm{E}$ & 410.0 & 316 & 53 & ?Eocene \\
743 & $66^{\circ} 54.994^{\prime} \mathrm{S}$ & $74^{\circ} 41.423^{\prime} \mathrm{E}$ & 987.0 & 98.1 & 22 & Pliocene-Quaternay \\
744 & $61.34 .656^{\prime} \mathrm{S}$ & $80^{\circ} 35.463^{\prime} \mathrm{E}$ & 2307.8 & 176.1 & 90 & late Eocene \\
745 & $59^{\circ} 35.710^{\prime} \mathrm{S}$ & $85^{\circ} 51.600^{\prime} \mathrm{E}$ & 4082.0 & 215 & $103^{*}$ & late Miocene \\
746 & $59^{\circ} 32.823^{\prime} \mathrm{S}$ & $85^{\circ} 51.780^{\prime} \mathrm{E}$ & 4059.0 & 281 & 75 & late Miocene \\
\hline
\end{tabular}

*Core expansion gave more than $100 \%$ recovery. 


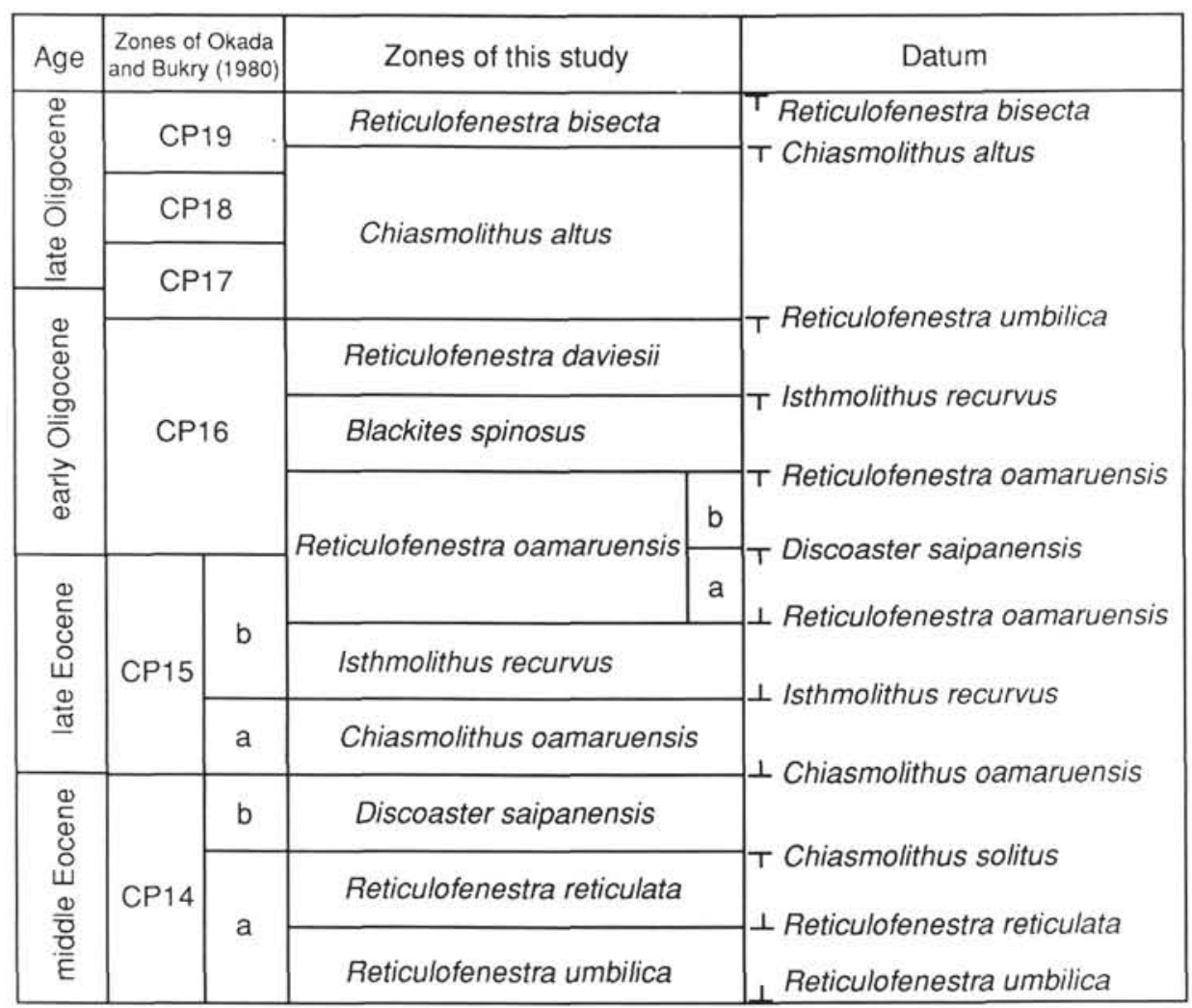

Figure 2. Calcareous nannofossil zonation used in this study to achieve a finer biostratigraphy for the middle Eocene to Oligocene and its correlation with the zonation of Okada and Bukry (1980). Modified slightly from Wei and Wise (1990). “P” indicates first occurrence and "T" denotes last occurrence.

$\mathrm{G}=$ Good: individual specimens exhibit little dissolution or recrystallization; delicate parts are preserved.

$\mathbf{M}=$ Moderate: dissolution (etching) and/or recrystallization (overgrowth) of individual specimens are apparent; identification of species are generally not impaired.

$\mathrm{P}=$ Poor: individual specimens exhibit considerable dissolution and/or recrystallization; identification of some species is not possible.

For Hole $738 \mathrm{C}$, the degree of etching and overgrowth was recorded separately, using a scale of $0-3$ as described by Roth and Thierstein (1972) and Roth (1973).

\section{KERGUELEN PLATEAU SITES}

Holes were drilled at two sites (Sites 736 and 737) on the northern Kerguelen Plateau, two sites (Sites 738 and 744) on the southern Kerguelen Plateau, and two sites (Sites 745 and 746) off the southern Kerguelen Plateau in deep waters (Fig. 1). These sites, along with those drilled by ODP Leg 120 in the central part of the Kerguelen Plateau, form excellent latitudinal and water depth transects for paleoceanographic studies. No calcareous nannofossils were recovered at Site 745 , which will not be discussed further.

\section{Site 736}

Site 736, the northernmost site on the ODP Legs 119 and 120 north-south paleoceanographic transect, lies beneath the modern Antarctic Convergence. A major objective of paleoceanographic studies at Site 736 was to trace the movement of the Antarctic Convergence through time using both sediment types and microfossil assemblages. The $\mathbf{3 7 1} \mathrm{m}$ of Pliocene through Quaternary sediments cored at this site is poor in carbonate, mainly consisting of siliceous ooze with interspersed volcanic debris and glacial dropstones.

Calcareous nannofossil are either absent or rare in all corecatcher samples investigated at this site. Sample 119-736A-1H, $0-2 \mathrm{~cm}$, from the mud line contains rare, well preserved Gephyrocapsa oceanica. For the next $250 \mathrm{~m}$ section, moderately to strongly etched specimens of Coccolithus pelagicus were encountered in the following core-catcher samples: 119-736A-9H (rare), -736A-25H (rare), -736A-27H (few), -736A-29H (common), $-736 \mathrm{~A}-30 \mathrm{H}$ (rare), -736C-4R (rare), -736C-5R (few), -736C-6R (rare), and -736C-7R (few). Sample 119-736C-7R-2, $66 \mathrm{~cm}$, from a thin layer (about $5 \mathrm{~cm}$ ) of calcareous nannofossil-diatom ooze at 257.2 meters below seafloor (mbsf) contained a well-preserved monospecific assemblage of Reticulofenestra producta. This species is rather small in size, commonly 3-4 $\mu \mathrm{m}$ (see discussion in the taxonomic note section), and is most abundant in high-latitude Pliocene sediments (Backman, 1980). Sample 119-736C8R-CC contains strongly etched C. pelagicus (few) and Gephyrocapsa sp. (rare). A few moderately preserved Reticulofenestra producta were also found in Sample 119-736C-9R-CC.

These calcareous nannofossils are of limited biostratigraphic value. The upper $280-\mathrm{m}$ sequence is assigned to the Pliocene or younger based on the presence of Reticulofenestra producta and the absence of Reticulofenestra perplexa. The absence or scarcity of calcareous nannofossils in the upper Neogene diatom ooze at such a shallow-water site $(629 \mathrm{~m})$ is due to unfavorable living conditions for the calcareous nannoplankton, rather than dissolution. 


\section{Site 737}

Site 737 is situated on the northern Kerguelen Plateau about $100 \mathrm{~km}$ southeast of Site 736 (Fig. 1). Major drilling objectives of Site 737 were similar to those of Site 736, and included recovery of a high-resolution reference section from the northern end of the Kerguelen Plateau-Prydz Bay transect (ODP Legs 119 and 120) for both biostratigraphic and paleoceanographic analyses. The $715.5 \mathrm{~m}$ middle Eocene through lower Pliocene section cored in two holes at Site 737 begins stratigraphically almost exactly where coring was terminated at Site 736 , so together, the two sites form a valuable reference section for the upper Paleogene through the Neogene at about $50^{\circ} \mathrm{S}$ in the Southern Ocean.

\section{Hole 737A (Table 2)}

The interval from the first core to Section 119-737A-2H-3 is barren of calcareous nannofossils. The rest of Core 119-737A-2H through Core 119-737A-5H yielded rare to common Reticulofenestra producta. Coccolithus pelagicus occurred only sporadically in this interval. Calcareous nannofossils occurred only sporadically farther downhole, until near the bottom of the hole (Cores 119-737A-26X through -28X), where abundant calcareous nannofossils of three to four species were found. The highest stratigraphic occurrence of Reticulofenestra perplexa (= Dictyococcites antarcticus $\mathrm{Haq}$, see taxonomic note) was recognized in Sample 119-737A-19X-1, 45-47 cm. Because this species has been found only in middle to upper Miocene sediments in other areas of the Southern Ocean (Haq, 1976; Haq et al., 1977; Wise, 1983; Wei and Wise, 1990), the Miocene/Pliocene boundary is believed to lie above this sample, consistent with the diatom data (Baldauf and Barron, this volume).

Because the preservation of the calcareous nannofossil assemblages, where present, is generally good at this shallow-water site, the low species diversity and low abundance of the nannofloras are probably due to lack of supply, rather than dissolution. The intervals where calcareous nannofossils occur may indicate periods of weaker upwelling and warmer surface water at Site 737.

\section{Hole 737B (Table 3, back pocket)}

The first and fourth cores from Hole 737B are wash cores and no samples were available for this study. Calcareous nannofossils are abundant from Core 119-737B-5R downhole. Cores 119-737B-5R to -7R yielded abundant Reticulofenestra perplexa, and are of middle-late Miocene age.

The ranges of several species, namely, Calcidiscus macintyrei, Chiasmolithus altus, Reticulofenestra bisecta, and Reticulofenestra daviesii, are truncated between Samples 119-737B-11R-1, $50-51 \mathrm{~cm}$, and $-11 \mathrm{R}-2,80-81 \mathrm{~cm}$, indicating the presence of a disconformity between these two samples. This disconformity coincides with the lithologic change (313.4 mbsf) from diatom nannofossil ooze above to calcareous claystone below.

The upper Oligocene can usually be subdivided by sphenolith datums in tropical or temperate regions. However, only one specimen of Sphenolithus ciperoensis was observed in Hole 737B, Sample 119-737B-15R-CC. The only other Sphenolithus species found in this hole is Sphenolithus moriformis, a ubiquitous species that has little biostratigraphic utility. No other datums are available to make a finer nannofossil biostratigraphy possible for the upper Oligocene in this hole.

The rare occurrence of Reticulofenestra umbilica in Sample 119-737B-34R-6, 73-75 cm, is considered reworked. The LO of Reticulofenestra umbilica is placed between Samples 119-737B34R-CC, and -35R-CC. Another species event worth noting is the LO of Clausicoccus fenestratus (= Clausicoccus subdistichus, see taxonomic note) in Sample 119-737B-37R-1, 45-46 $\mathrm{cm}$, where the species is abundant. This datum level is located between the LO of Reticulofenestra umbilica and that of Isthmolithus recurvus. A similar succession was observed at Sites 511 and 513 (Leg 71) at about the same latitude in the South Atlantic Ocean, where Wise (1983) used the LO of Clausicoccus fenestratus as a zonal marker in the lower Oligocene. This datum seems to be useful for biostratigraphic correlation at latitudes near $50^{\circ} \mathrm{S}$. However, the biostratigraphic range of $C$. fenestratus has been shown to become shorter at higher latitudes and longer at lower latitudes (Wei and Wise, 1990). The LO of Isthmolithus recurvus is located at Sample 119-737B-37R-5, 45$46 \mathrm{~cm}$. This species event has a relatively consistent age around 34.9 Ma from middle to high latitudes (Wei and Wise, 1989a, 1990 ) and is therefore useful for subdivision of the lower Oligocene sediments recovered by Leg 119 .

The LO of Coccolithus formosus was observed in Sample 119-737B-38R-4, 126-127 cm. This datum was used to define the bottom of Subzone CP16c by Okada and Bukry (1980), but is not useful for Site 737, because the datum is below the end of C. fenestratus acme in Hole 737B, the reverse of the sequence observed at lower latitudes.

The LO of Discoaster saipanensis is placed above Sample 119-737B-41R-2, 102-103 cm, and defines the Eocene/Oligocene boundary in terms of calcareous nannofossil biostratigraphy. Reticulofenestra oamaruensis, the range of which straddles the Eocene/Oligocene boundary, was found only in Sample $119-737 \mathrm{~B}-41 \mathrm{R}-3,132-133 \mathrm{~cm}$. This may be due to very low abundance of the species, a hiatus at this site, and/or poor preservation of the species, which becomes indistinct when the central area is dissolved.

The ranges of Isthmolithus recurvus and Reticulofenestra reticulata overlap in one sample only (Sample 119-737B-46R-1, 1$2 \mathrm{~cm}$ ). This overlap is considerably shorter than at the lower latitudes, and is due to progressively earlier disappearance of $R e$ ticulofenestra reticulata toward the higher latitudes, rather than to a condensed section or hiatus (see further discussion in the following text). Similar to the observation of Wei and Wise (1989a, 1990) at Sites $516(\operatorname{Leg} 72)$ and $689(\mathrm{Leg} \mathrm{113)}$ in the South Atlantic, larger specimens $(8-11 \mu \mathrm{m})$ of $R$. reticulata were found in the upper range of the species in Hole 737B, and smaller (generally less than $8 \mu \mathrm{m}$ ) specimens were observed in its lower range.

Samples 119-737B-46R-1, 90-91 cm, and -46R-2, 21-22 cm, are assigned to the Chiasmolithus oamaruensis Zone (Subzone $\mathrm{CP} 15 \mathrm{a}$ ) based on the first occurrence of Isthmolithus recurvus above the former sample and the first occurrence of Chiasmolithus oamaruensis in the latter sample. Chiasmolithus altus occurs farther downhole than $C$. oamaruensis, a situation similar to that at two higher latitude sites (689 and 690 on Leg 113) in the Weddell Sea (Wei and Wise, 1990). This sequence of events is opposite to that normally found at lower latitudes (PerchNielsen, 1985a).

Two specimens of Chiasmolithus solitus were seen in Sample 119-737B-47R-1, 44-45 cm, and they are probably reworked. The generally poor preservation of the nannoflora in Cores 119 $737 \mathrm{~B}-47 \mathrm{R}$ and $-48 \mathrm{R}$ hinders the precise location of the $\mathrm{LO}$ of $C$. solitus, which is tentatively placed between Samples 119-737B48R-3, 46-47 cm, and -48R-CC.

Reticulofenestra umbilica was found down to the bottom of the hole. In addition, a few specimens of Discoaster bifax were also observed at the bottom of the hole and in Sample 119737B-52R-3, 121-122 cm. The presence of these two species constrains the oldest sediment in Hole 737B to be Subzone CP14a (middle Eocene). 
Table 2. Distribution of calcareous nannofossils, Hole 737A.

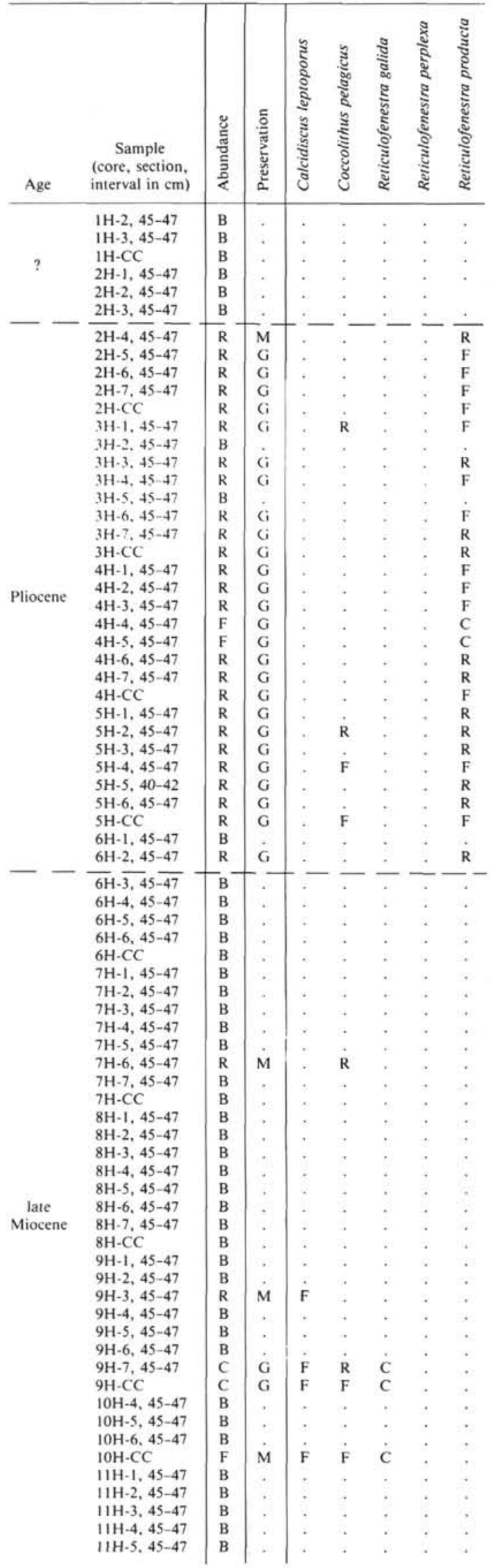

Table 2 (continued).

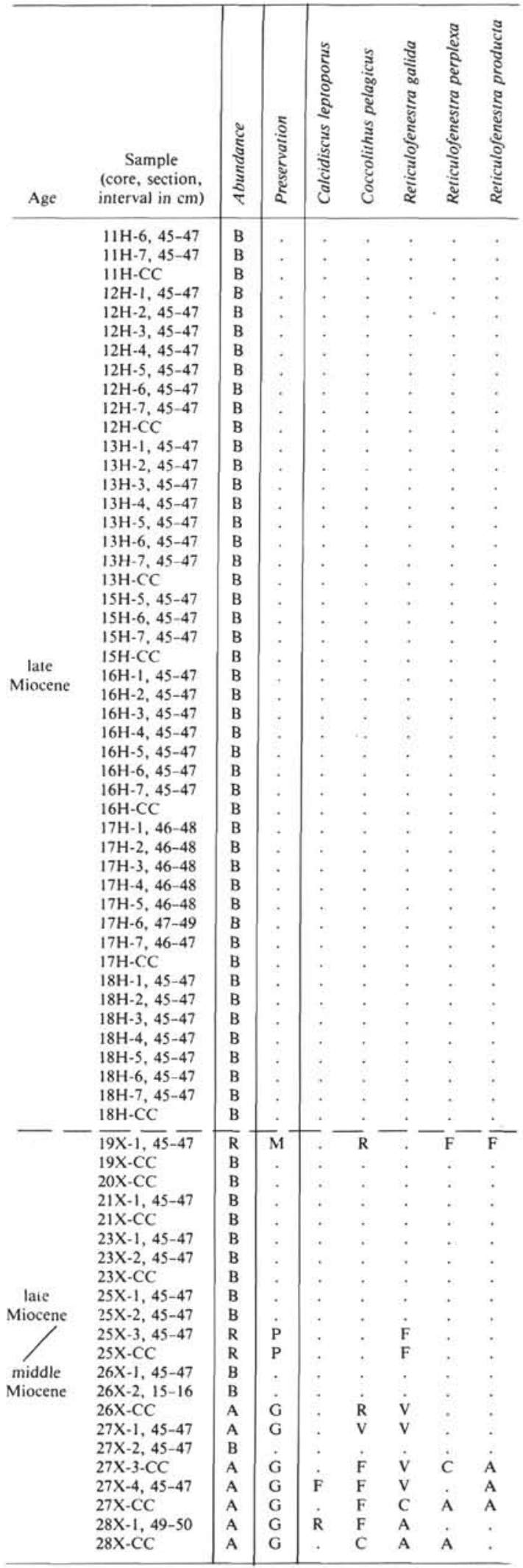

Note: Abundance is characterized by $\mathrm{V}$, very abundant; $\mathrm{A}$, abundant; C, common; F, few; R, rare; B, barren. For preservation, G, good M, moderate; P, poor 


\section{Site 738}

Site 738 is located on the southern tip of the Kerguelen Plateau (Fig. 1). This site lies north of the modern Antarctic Divergence and near the southern limit of influence of the Antarctic Circumpolar Current. Drilling at Site 738 was to provide the southernmost pelagic record for documentation of changes in Late Cretaceous and Cenozoic climate of the southern Indian Ocean and to recover basement samples to investigate the origin and history of the Kerguelen Plateau.

Three holes were drilled at this site and a 490-m-thick lower Turonian through Quaternary pelagic sediment sequence plus 43 $\mathrm{m}$ of basaltic breccia and altered basalt in the basement were cored. Calcareous nannofossils are rare to common but occur sporadically in the condensed Neogene section. They are abundant and moderately preserved in the expanded ( $360 \mathrm{~m}$ thick) Paleogene section. Reworking of calcareous nannofossils is minimal. A relatively complete Danian section was recovered. A quantitative nannofossil study of this high-latitude Danian section is presented by Wei and Pospichal (this volume). In addition, an apparently complete Cretaceous/Tertiary boundary was recovered at this site. Detailed discussion of this boundary is provided by Thierstein et al. (this volume). The relatively continuous Upper Cretaceous sequence recovered at Site 738 is the first from the Indian Ocean sector of the Southern Ocean to extend the stratigraphic record as far back as early Turonian.

\section{Hole 738A}

Hole $738 \mathrm{~A}$ only penetrated $2.80 \mathrm{~m}$ and recovered $2.76 \mathrm{~m}$ sediment, when technical problems prompted the drilling of a new hole (Hole 738B). One sample examined from this hole, Sample 119-738A-1H-CC, contains rare Calcidiscus leptoporus, Coccolithus pelagicus, Geophyrocapsa caribbeanica, Helicosphaera kamptneri, and Pseudoemiliania lacunosa, an assemblage of early-middle Pleistocene age. As no calcareous nannoplankton have been found in the modern ocean at this latitude, the presence of the lower Pleistocene calcareous nannofossils at Site 738 may indicate that surface waters during part of the early Pleistocene were significantly warmer than today.

\section{Hole $738 B$ (Table 4, back pocket)}

The first two cores from Hole 738B yielded few Coccolithus pelagicus and rare Gephyrocapsa oceanica. Beginning from the middle of Core 119-738B-3H, calcareous nannofossils are abundant or very abundant throughout the rest of the hole. Samples 119-738B-3H-3, 43-44 cm, and -3H-3, 66-68 cm, contain Reticulofenestra gelida and Reticulofenestra perplexa and are of Miocene age.

Sample 119-738B-3H-4, 66-68 cm, contains Chiasmolithus altus, Isthmolithus recurvus, Reticulofenestra daviesii, Reticulofenestra umbilica, and a few other species. This is an early Oligocene assemblage of the Blackites spinosus Zone (about 35-36 Ma). A major disconformity thus exists between this sample and the overlying Miocene sample (Sample 119-738B-3H-3, 66$68 \mathrm{~cm}$ ). This disconformity is similar to the one found at Site 737 on the northern Kerguelen Plateau associated with the $\mathrm{Pa}$ leogene/Neogene boundary.

Reticulofenestra oamaruensis, a useful marker in the Southern Ocean (Edwards, 1971; Wise, 1983; Wei and Wise, 1990), was found in Samples 119-738B-4H-2, 66-68 cm, through -5H-2, $66-68 \mathrm{~cm}$. Therefore, this interval can be placed into the Reticulofenestra oamaruensis Zone. The Eocene/Oligocene boundary should lie within this zone, but the paucity of Discoaster saipanensis and Discoaster barbadiensis in this hole prevented the use of their last occurrences for delineating the Eocene/Oligocene boundary at this site.

The lower boundary of the Isthmolithus recurvus Zone was drawn between Samples 119-738B-5H-5, 110-111 cm, and -5H-6,
66-68 cm, based on the first occurrence (FO) of Isthmolithus recurvus in the former sample. The latter sample contains Reticulofenestra reticulata. This lack of range overlap of the two species has previously been found at other high-latitude sites (Wei and Wise, 1990) and is due to time transgression of the LO of $R$. reticulata with latitude rather than a hiatus.

The FO of Reticulofenestra bisecta was found within the Chiasmolithus oamaruensis Zone (Subzone CP15a), slightly younger (about $1 \mathrm{~m} . \mathrm{y}$.) than at Site 737 to the north, but significantly younger than at middle or low latitudes. A time transgression of the FO of $R$. bisecta across latitudes is, therefore, apparent.

Reticulofenestra daviesii, a cold-water species, is generally abundant in this hole, but is rare or absent within some intervals in Core $119-738 \mathrm{~B}-6 \mathrm{H}$, as well as in several cores downhole (see Table 4). These intervals may represent relatively warm events.

The FO of Chiasmolithus oamaruensis and the LO of Chiasmolithus solitus are truncated between Samples 119-738B-8H-CC, and $-9 \mathrm{H}-1,66-68 \mathrm{~cm}$. Thus the Discoaster saipanensis Zone (or Subzone CP14b) is missing due to a disconformity. A similar disconformity was also found at Site 690 in the Weddell Sea but not at Site 689 (slightly north of Site 690) (Wei and Wise, 1990).

The highest stratigraphic occurrence of Coccolithus formosus was found in Sample 119-738B-10H-3, 66-68 cm, within Subzone CP14a, considerably lower than at Site 737, where it can still be used to mark the top of Subzone CP16b as at lower latitudes. The decrease in abundance of $C$. formosus is drastic south of $50^{\circ} \mathrm{S}$ latitude, and this conventional marker species is not useful in the higher latitudes.

The FO of Reticulofenestra umbilica was placed between Samples 119-738B-15X-1, 66-68 cm, and $-15 \mathrm{X}-2,66-68 \mathrm{~cm}$. The smaller forms $(<14 \mu \mathrm{m})$ of $R$. umbilica, namely, Reticulofenestra samodurovii, are still common below this level. Interestingly, a few specimens of $R$. umbilica (14-15 $\mu \mathrm{m})$ were observed farther downhole in Samples 119-738B-18X-1, 66-67 cm, $-18 \mathrm{X}-3,66-67 \mathrm{~cm}$, and $-18 \mathrm{X}-4,66-67 \mathrm{~cm}$. This phenomenon of sporadic, rare occurrences of $R$. umbilica at unusually low levels was also observed in the North Atlantic Ocean (Firth, 1989). It is clear that the FO of this species should not be taken at its "absolute" first occurrence, but as the level of sudden increase in abundance. Above this level specimens $16 \mu \mathrm{m}$ or larger are generally common.

Only sporadic Nannotetrina cristata and Nannotetrina fulgens were observed in Hole 738B. The FO of $N$. cristata is used instead of $N$. fulgens for defining the base of the Nannotetrina fulgens Zone (CP13) in this study, as suggested by Perch-Nielsen (1985) for less than ideally preserved material. Because of the scarcity of $N$. cristata in Hole 738B, the lower boundary of the $N$. fulgens Zone (lower middle Eocene) in Table 4 should be considered tentative and may be stratigraphically lower.

Few Discoaster sublodoensis and rare Discoaster lodoensis were seen in the lowest sample from this hole (Sample 119738B-24X-CC). The bottom of the hole, therefore, should be placed in the Discoaster sublodoensis Zone (CP12).

\section{Hole 738 C (Table 5, back pocket)}

The first core in this hole is a wash core and no sample was available. Core 119-738C-2R was taken at about the same depth as the last core in Hole 738B (Core 119-738B-24X). It also contains rare Nannotetrina cristata and can be placed in Zone CP13. Discoaster sublodoensis was found down to Sample 119738C-5R-1, 69-70 cm, which is taken as the base of Zone CP12. Discoaster praebifax occurs in Cores $119-738 \mathrm{C}-3 \mathrm{R}$ to $-5 \mathrm{R}$, further supporting the age assignment of CP12-13 for this interval (Wei and Wise, 1989b).

Rare occurrences of Tribrachiatus orthostylus in Sample 119$738 \mathrm{C}-5 \mathrm{R}-2,69-70 \mathrm{~cm}$, are probably due to reworking, and the LO of $T$. orthostylus should probably be placed just above Sam- 
ple $119-738 \mathrm{C}-8 \mathrm{R}-1,66-68 \mathrm{~cm}$. However, there are still some uncertainties concerning the use of the $\mathrm{LO}$ of $T$. orthostylus as a marker for the base of Zone CP10 (Bukry, 1973; Perch-Nielsen, 1985a; Wei and Wise, 1989a). We therefore do not rely on the LO of $T$. orthostylus, and combine Zones CP10 and CP11 in Hole $738 \mathrm{C}$. The base of Zone CP11 is defined by the FO of Discoaster lodoensis, which was determined in Sample 119-738C8R-CC. The FO of Discoaster diastypus was found in Sample 119-738C-10R-CC, which is taken as the base of Zone CP9.

Discoaster multiradiatus was found down to Sample 119$738 \mathrm{C}-11 \mathrm{R}-\mathrm{CC}$, and the bottom of Zone CP8 can be placed below this sample. Core $119-738 \mathrm{C}-12 \mathrm{R}$ did not recover any sediments, and Cores 119-738C-13R, -14R, and -15R have less than $2 \%$ core recovery. This has limited the biostratigraphic resolution for this stratigraphic interval. Samples 119-738C-13R-CC, and -14R-CC, contain Discoaster mohleri but no Discoaster multiradiatus or Discoaster nobilis. The two samples are thus assigned to the combined Zones CP6-7. Sample 119-738C-15R-CC has no D. mohleri, but contains Heliolithus kleinpellii, and should be placed in Zone CP5. Fasciculithus tympaniformis and Chiasmolithus bidens were found down to Sample 119-738C-17R-CC, which should be the base of Zone CP4. Sphenolithus primus was observed only down to Sample 119-738C-16R-CC. This species apparently occurs later than $F$. tympaniformis at this high latitude, a reversed succession of that at middle or low latitudes (see Perch-Nielsen, 1985a, p. 436).

Sample 119-738C-18R-CC contains Chiasmolithus danicus, Prinsius martinii, and several other species but no fasciculiths, and thus belongs to Zones CP2-3. The lowest occurrence of Cruciplacolithus tenuis was found in Sample 119-738C-20R-5, $70.5 \mathrm{~cm}$, which is taken as the base of Subzone CP1b. Cruciplacolithus primus were found only sporadically in this hole. Detailed discussion of calcareous nannofossil assemblages and nannofossil biostratigraphy of Cores $119-738 C-17 R$ through $-20 R$ is provided by Wei and Pospichal (this volume).

A detailed stratigraphical study was performed in Section 119-738C-20R-5, which contains the Cretaceous/Tertiary boundary (see also Thierstein et al., this volume). The observable lithologic succession is a dark chert layer $(103-118 \mathrm{~cm})$ overlain by lithified, bioturbated, white chalk (103-96.2 cm) which contains green laminae in the uppermost $2 \mathrm{~cm}$. These chalks are composed dominantly of micrite particles and contain an upper Maastrichtian nannofossil assemblage. Overlying this is a distinct, thin, gray clay layer $(96.2-96.0 \mathrm{~cm})$ (Fig. 3), which contains an iridium concentration peak (see Schmitz and Asario, this volume) and is, therefore, considered an equivalent of similar K/T boundary clays reported from other areas. Immediately above the $\mathrm{K} / \mathrm{T}$ boundary clay is a 14-cm-thick interval of finely laminated white to green soft chalk $(96-82 \mathrm{~cm})$. Within this laminated interval the lowermost consistent occurrences of Markalius inversus (both oval and circular morphotypes), Hornibrookina teuriensis, Prinsius dimorphosus, Zygodiscus sigmoides, and Thoracosphaera spp. (including other calcified dinoflagellate cysts, such as Orthopithonella congrenta and Centrosphaera barbata) were observed. The interval also contains the lowermost occurrences of sporadic Biantholithus sparsus and Cruciplacolithus primus. The first occurrences of these taxa are known from lowermost Danian sediments of other Cretaceous/Tertiary boundary sections, such as in Denmark (Perch-Nielsen, 1979), Gubbio (Monechi and Thierstein, 1985), Caravaca (Romein, 1979), and El Kef (Perch-Nielsen et al., 1982). Rare Markalius inversus (oval) and Thoracosphaera spp. (including fragments of other calcareous dinoflagellate cysts) have been found in uppermost Cretaceous assemblages of other geographic areas (Thierstein, 1981) and the presence of Cruciplacolithus tenuis and Toweius sp. below Sample 119-738C-20R-5, $80 \mathrm{~cm}$, i.e., at a level considerably below their known and continuously recorded presence, must be downhole contaminants, as confirmed by

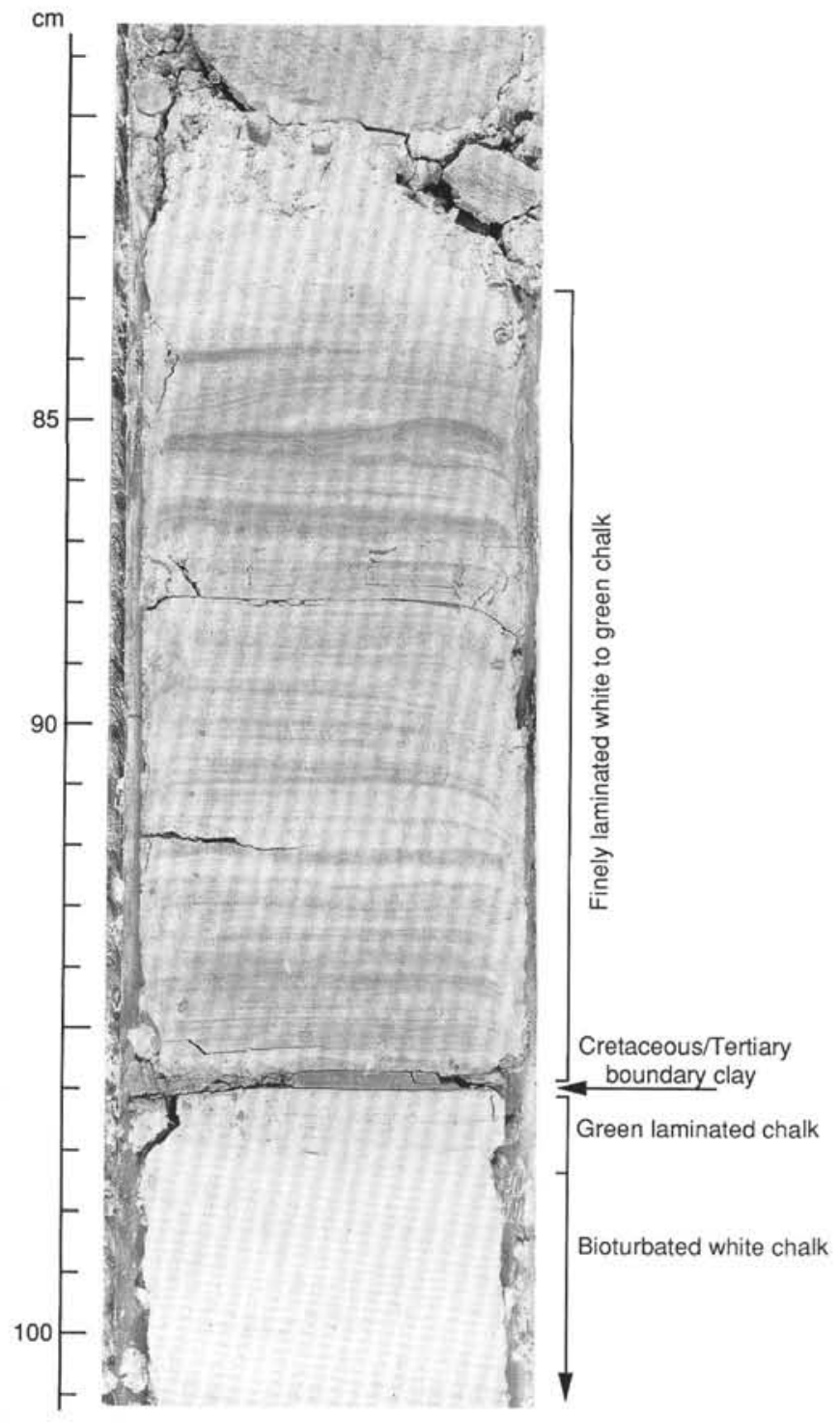

Figure 3. Lithology across the Cretaceous/Tertiary boundary in Section 119-738C-20R-5, 79-101 cm.

their abundance in light colored oozes smeared between core liner and sediment in the same level (see also discussion in Thierstein et al., this volume). Upward from Sample 119-738C$25 \mathrm{R}-5,80 \mathrm{~cm}$, are layers of semilithified, bioturbated chalks, which are interrupted by seams of crushed drilling breccia and soft white ooze. In the lowermost sample of the semilithified chalk at $80.2 \mathrm{~cm}$ the proportion of the newly evolving Tertiary nannofossil taxa attain $85 \%$ of the total (see Thierstein et al., this volume). The well-known replacement of the uppermost Cretaceous nannofossil assemblage by the early Tertiary nannofossil assemblage, thus, is gradual over a few centimeters within the laminated interval between the clay layer at $96 \mathrm{~cm}$ and the base of the semilithified chalk at $80 \mathrm{~cm}$.

The Upper Cretaceous lithified chalk and limestone sequence yielded a seemingly continuous lower Turonian to upper Maastrichtian succession of poorly to moderately preserved nannofossil assemblages. Within the middle part of the Maastrichtian a possibly short break in sedimentation was identified.

The taxonomic composition of the mostly poorly preserved upper Maastrichtian assemblages in samples from Sections 119$738 \mathrm{C}-20 \mathrm{R}-5$ to $-24 \mathrm{R}-1$ (377.16-409.1 mbsf) is comparable to 
that of other high-latitude areas (Thierstein, 1976, 1981). The assemblages are dominated by relatively resistant high-latitude taxa, such as Nephrolithus frequens, Arkhangelskiella cymbiformis, Kamptnerius magnificus, and Lucianorhabdus cayeuxii, together with cosmopolitan Prediscosphaera cretacea, Micula staurophora, and Biscutum constans. Low-latitude taxa, such as Watznaueria barnesae, Micula murus, and Cylindralithus $\mathrm{sp.}$ are rare or absent. The first occurrence of Nephrolithus frequens has been shown to be just below that of Micula murus in magnetic Subchron 30N (Thierstein, 1976, 1981; Manivit, 1984; Chave, 1984) and is thus considered correlative to NC23 (Roth, 1978).

A late Campanian to early Maastrichtian age for the interval $119-738 \mathrm{C}-26 \mathrm{R}-2$ to $-26 \mathrm{R}-\mathrm{CC}$ (430.7-438 mbsf) is documented by the presence of rare to few Broinsonia parca, whose stratigraphic range is known to extend from magnetic Subchron 33R to Subchron 32N, i.e., NC18-20 (Stradner and Steinmetz, 1984; Monechi and Thierstein, 1985). The overlying interval (409.1-430.7 mbsf) represents the early to middle Maastrichtian (NC19-20), because it includes the highest occurrences of rare Eiffellithus eximus, rare to few Reinhardtites levis (up to Sample 119-738C24R-CC), and rare to common Biscutum coronum. The latter species was considered to be latest Campanian to earliest Maastrichtian age by Wise (1983) and thus the middle part of the Maastrichtian may be missing. Surprisingly, Monomarginatus sp. or Miseomarginatus pleniporus, commonly found in Upper Cretaceous assemblages from the Falkland Plateau, were not found at Site 738; this may point to the bioprovincial peculiarity of the Falkland Plateau.

A Santonian age (NC16-17) is inferred for the interval 119738C-27R-2 to -29R-CC (439.6-466.6 mbsf), which includes the last occurrence of Lithastrinus floralis, a middle Santonian event (Thierstein, 1976; Wise, 1983; Perch-Nielsen, 1985b) and the first occurrence of Reinhardtites anthoporus, an early Santonian event (Wise, 1983; Perch-Nielsen, 1985b). Other marker species of previously proposed high-latitude zonations, such as Marthasterites furcatus or Thiersteinia eccleslastica were not found at Site 738. Core 119-738C-31R (467.6-476.3 mbsf) is assigned lower Turonian to Coniacian age (NC13-15) because it includes the first occurrence of Micula staurophora (Thierstein, 1976; equivalent to Quadrum gartneri of Manivit et al., 1977). The assemblages in Core 119-738C-31R lack that species, but document the first occurrence of Kamptnerius magnificus and the last occurrence of Gartnerago nanum which can be correlated to earliest Turonian assemblages elsewhere (Bralower, 1988). The lowermost chalk recovered in Core 119-738C-31R is in depositional contact with volcanic basement and is considered to be of early Turonian age.

\section{Site 744}

Site 744 was cored on the southern Kerguelen Plateau in order to recover a more complete Neogene and Oligocene section than at Site 738. Three holes were drilled at Site 744 and sediments recovered range from upper Eocene to Holocene. Calcareous nannofossils are sporadic in the Pliocene-Holocene interval and are abundant throughout the lower sequence.

\section{Hole 744 A (Table 6, back pocket)}

Rare specimens of Pseudoemiliania lacunosa are present in the first core-catcher sample, and indicate an age of late Pliocene-middle Pleistocene. Reticulofenestra gelida is common in Cores $119-744 \mathrm{~A}-4 \mathrm{H}$ and $-5 \mathrm{H}$, whereas Reticulofenestra pseudoumbilica is absent in this hole. This contradicts the hypothesis of Backman (1980) that $R$. gelida is a winter morphotype of $R$. pseudoumbilica (see further discussion of $R$. gelida in the following taxonomic note).

The LO of Reticulofenestra bisecta is placed between Samples $119-744 \mathrm{~A}-11 \mathrm{H}-\mathrm{CC}$, and $-12 \mathrm{H}-1,92-93 \mathrm{~cm}$. This datum de- fines the Oligocene/Miocene boundary in terms of calcareous nannofossil biostratigraphy. Rare $R$. bisecta and chiasmoliths above this level are considered reworked. The LO of Chiasmolithus altus was determined in Sample 119-744A-12-6, 92-93 $\mathrm{cm}$, where it is abundant. Correlation with magnetostratigraphy at middle-latitude Site 516 (Leg 72) suggests an age of $27.0 \mathrm{Ma}$ for this datum (Wei and Wise, 1989a). Since C. altus is more abundant in high latitudes than in temperate regions, some diachroneity of its extinction across latitudes is expected, and its LO at Site 744 may be slightly younger than $27.0 \mathrm{Ma}$.

Consistent occurrences of Reticulofenestra samodurovii and Reticulofenestra umbilica were found from Sample 119-744A$14 \mathrm{H}-\mathrm{CC}$, and downhole. The top of Zone CP16 is, therefore, drawn between Sample 119-744A-14H-6, 75-76 cm, and -14H-CC. Rare and sporadic occurrences of $R$. samodurovii and $R$. umbilica above this level are considered reworked. Rare, reworked specimens of Isthmolithus recurvus were also found in the upper Oligocene and Miocene sediments. This is the only Leg 119 site on the Kerguelen Plateau that shows extensive reworking of the calcareous nannofossils in the upper Oligocene and Miocene.

The range of Reticulofenestra oamaruensis is useful for biostratigraphic subdivision of the upper Eocene-lower Oligocene at Site 744, as at other sites in the Southern Ocean (Stradner and Edwards, 1968; Wise, 1983; Wei and Wise, 1990). Discoaster saipanensis is rare and sporadic; its last occurrence is placed in Sample 119-744A-19H-4, 75-76 cm. The Eocene/Oligocene boundary in terms of calcareous nannofossil biostratigraphy is traditionally defined by the LO of $D$. saipanensis. However, the species, as other species of Discoaster, disappeared earlier at higher latitudes where temperatures are less favorable for Discoaster. Therefore, the Eocene/Oligocene boundary placed between Samples 119-744A-19H-3, 75-76 cm, and -19H-4, 75-76 $\mathrm{cm}$, is tentative. Similar to the situation at Site 738, the range of Reticulofenestra reticulata does not overlap with that of Isthmolithus recurvus. This differs from middle- or low-latitude successions and is due to the earlier extinction of $R$. reticulata at higher latitudes (Wei and Wise, 1990).

Paleomagnetic polarity data (Barron, Larsen, et al., 1989) and strontium isotopic data (Barrera et al., this volume; Wei and Wise, unpubl. data) are available for Hole 744A. Based on biostratigraphic and strontium isotopic data and comparison of the paleomagnetic polarity patterns with those in the reference polarity time scale of Berggren et al. (1985), magnetostratigraphy has been established for Hole 744A (see Barron et al., this volume for details). Correlation of Paleogene nannofossil datums with magnetostratigraphy in Hole $744 \mathrm{~A}$ is presented in Figure 4.

\section{Hole $744 B$ (Table 7)}

Hole 744B was cored to 78.5 mbsf using the advanced piston corer, and achieved a core recovery rate of $101.6 \%$ (core expansion gave more than $100 \%$ recovery). This relatively complete diatom nannofossil ooze section offers an excellent opportunity for biomagnetostratigraphic correlation and will be very useful for paleoceanographic studies of the Neogene.

Abundant Reticulofenestra perplexa were first encountered in Sample 119-744B-3H-CC, and is assigned to the middle-late Miocene. Downhole, Coccolithus pelagicus and one or two species of Reticulofenestra exhibit extreme fluctuations in assemblage dominance. This phenomenon has been seen in many Miocene sections from the Southern Ocean, such as at Site 737 on the northern Kerguelen Plateau, Site 329 (Leg 36) on the Falkland Plateau (Haq, 1980), and Sites 689 and 690 (Leg 113) in the Weddell Sea (Wei and Wise, 1990). Haq (1980) attributed these sharp fluctuations to climatically induced latitudinal migrations of Antarctic water assemblages during the Miocene. 


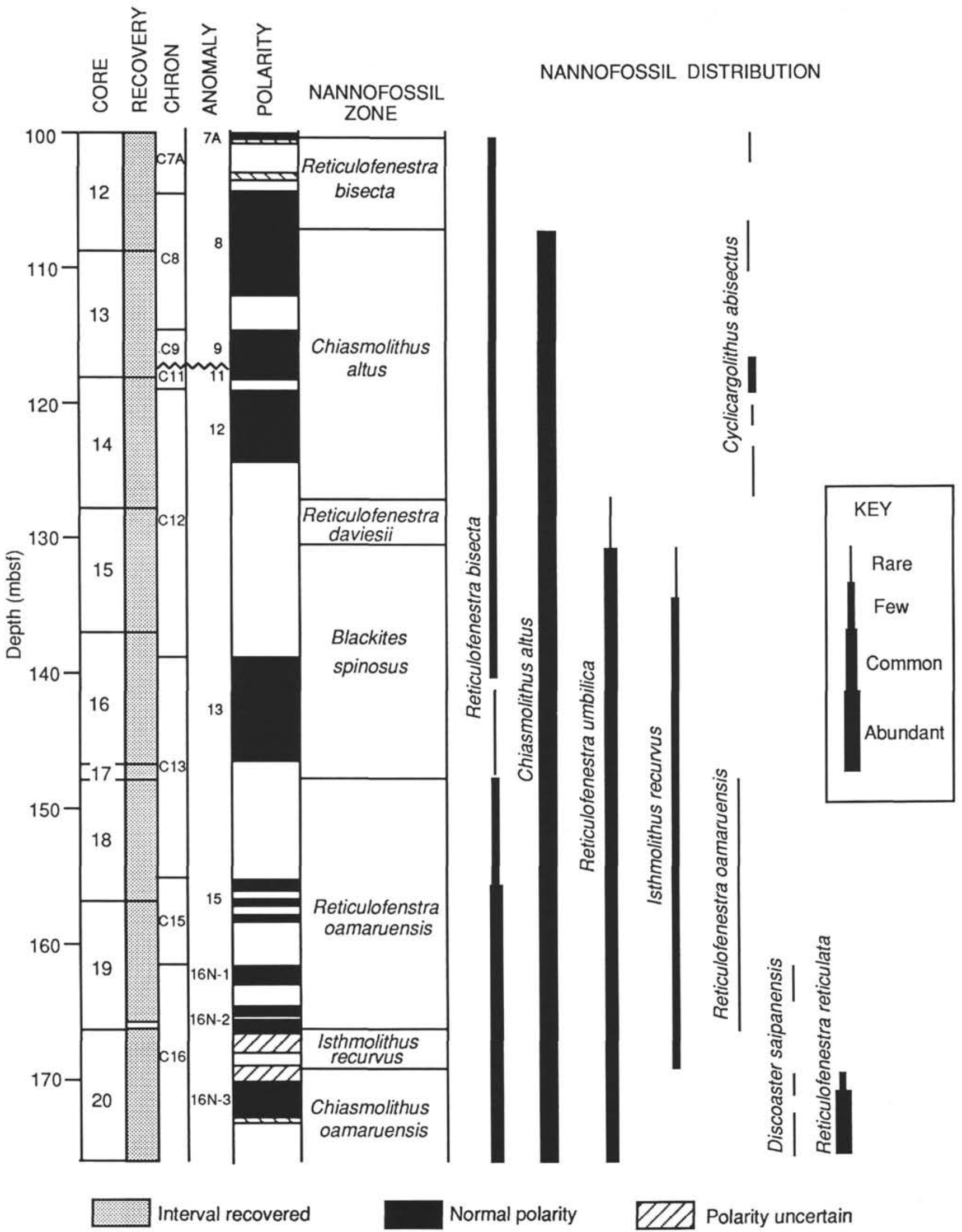

Figure 4. Correlation of simplified distribution patterns of calcareous nannofossil markers with magnetostratigraphy in Hole 744A, upper Eocene through Oligocene interval. Geomagnetic polarity data from Keating (this volume). Geomagnetic chron assignment is based on biostratigraphic and strontium isotopic data (see Barron et al., this volume, for details). 
Table 7. Distribution of calcareous nannofossils, Hole 744B.

\begin{tabular}{|c|c|c|c|c|c|c|c|c|c|c|c|c|c|c|c|c|c|c|}
\hline Age & Zone & $\begin{array}{c}\text { Sample } \\
\text { (core, section, } \\
\text { interval in } \mathrm{cm} \text { ) }\end{array}$ & 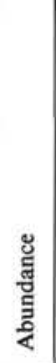 & 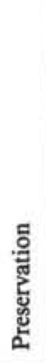 & 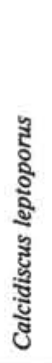 & 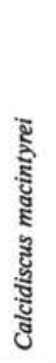 & 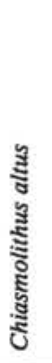 & 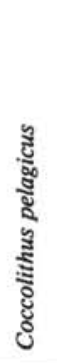 & 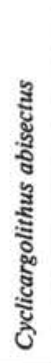 & 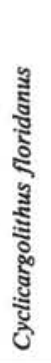 & 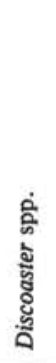 & 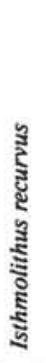 & 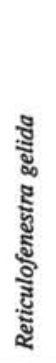 & 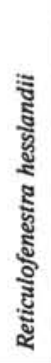 & 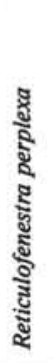 & 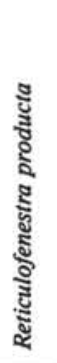 & 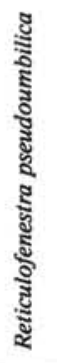 & 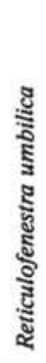 \\
\hline Pleistocene & & $\begin{array}{l}1 \mathrm{H}-\mathrm{CC} \\
2 \mathrm{H}-\mathrm{CC}\end{array}$ & $\begin{array}{l}\text { C } \\
\text { B }\end{array}$ & $\begin{array}{l}\mathrm{M} \\
.\end{array}$ & . & $i$ & $\dot{ }$ & $\begin{array}{l}\text { C } \\
\text {. }\end{array}$ & i & . & $\dot{.}$ & & $\dot{0}$ & 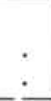 & $\dot{.}$ & . & . & $\dot{ }$ \\
\hline 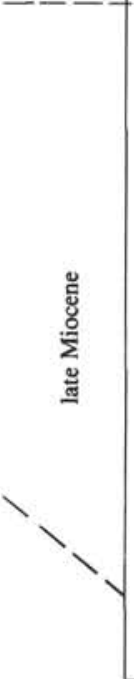 & $\overbrace{\mathrm{CN} 5 \mathrm{~b}}^{\mathrm{CN} 10}$ & $\begin{array}{l}3 \mathrm{H}-\overline{\mathrm{CC}} \\
4 \mathrm{H}-1,110-111 \\
4 \mathrm{H}-2,110-111 \\
4 \mathrm{H}-3,110-111 \\
4 \mathrm{H}-4,110-111 \\
4 \mathrm{H}-5,110-111 \\
4 \mathrm{H}-6,110-111 \\
4 \mathrm{H}-\mathrm{CC} \\
5 \mathrm{H}-1,110-111 \\
5 \mathrm{H}-2,110-111 \\
5 \mathrm{H}-3,110-111 \\
5 \mathrm{H}-4,110-111 \\
5 \mathrm{H}-5,110-111 \\
5 \mathrm{H}-6,110-111 \\
5 \mathrm{H}-\mathrm{CC} \\
6 \mathrm{H}-1,110-111 \\
6 \mathrm{H}-2,110-111 \\
6 \mathrm{H}-3,110-111 \\
6 \mathrm{H}-4,110-111 \\
6 \mathrm{H}-5,110-111 \\
6 \mathrm{H}-6,110-111 \\
6 \mathrm{H}-\mathrm{CC} \\
7 \mathrm{H}-1,110-111 \\
7 \mathrm{H}-2,110-111\end{array}$ & $\begin{array}{l}\text { A } \\
\text { R } \\
\text { A } \\
\text { A } \\
\text { A } \\
\text { A } \\
\text { A } \\
\text { A } \\
\text { A } \\
\text { A } \\
\text { A } \\
\text { A } \\
\text { A } \\
\text { A } \\
\text { A } \\
\text { A } \\
\text { A } \\
\text { A } \\
\text { A } \\
\text { A } \\
\text { A } \\
\text { A } \\
\text { A } \\
\text { A }\end{array}$ & $\begin{array}{l}M \\
P \\
M \\
\text { M } \\
G \\
G \\
G \\
G \\
G \\
G \\
G \\
G \\
G \\
G \\
G \\
G \\
G \\
G \\
G \\
G \\
G \\
G \\
G \\
G \\
G \\
G \\
G\end{array}$ & $\begin{array}{l}\mathrm{R} \\
\vdots \\
\vdots \\
\vdots \\
\dot{\mathrm{R}} \\
\mathrm{R} \\
\mathrm{F} \\
\dot{\mathrm{R}} \\
\mathrm{A} \\
\mathrm{R} \\
\mathrm{R} \\
\dot{2} \\
\vdots \\
\vdots \\
\dot{\mathrm{R}} \\
\mathrm{R}\end{array}$ & 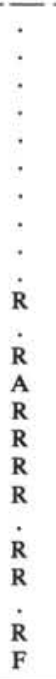 & 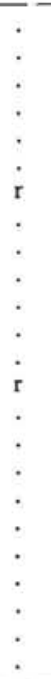 & $\begin{array}{l}\text { A } \\
\text { C } \\
\text { A } \\
\text { A } \\
\text { V } \\
\text { C } \\
\text { R } \\
\text { F } \\
\text { A } \\
\text { A } \\
\text { A } \\
\text { C } \\
\text { F } \\
\text { R } \\
\text { F } \\
\text { F } \\
\text { R } \\
\text { F } \\
\text { R } \\
\text { R } \\
\text { F } \\
\text { F } \\
\text { R }\end{array}$ & $\begin{array}{l}: \\
: \\
: \\
: \\
: \\
: \\
: \\
: \\
: \\
:\end{array}$ & $\begin{array}{l}: \\
: \\
: \\
: \\
: \\
: \\
: \\
: \\
: \\
: \\
: \\
: \\
.\end{array}$ & 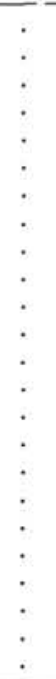 & $\begin{array}{l}\vdots \\
\vdots \\
\vdots \\
\vdots \\
\vdots \\
\vdots \\
\vdots \\
\vdots \\
\vdots \\
\vdots \\
\vdots \\
\vdots \\
\vdots\end{array}$ & $\begin{array}{l}\mathrm{C} \\
\dot{\mathrm{C}} \\
\mathrm{C} \\
\mathrm{C} \\
\mathrm{F} \\
\mathrm{C} \\
\cdot \\
\dot{\mathrm{A}} \\
\mathrm{C} \\
\mathrm{C} \\
\mathrm{A} \\
\mathrm{F} \\
\mathrm{F} \\
\mathrm{R} \\
\dot{.} \\
\dot{0} \\
\dot{.} \\
\dot{\mathrm{R}} \\
\mathrm{F} \\
\mathrm{F}\end{array}$ & $\begin{array}{l}: \\
: \\
: \\
: \\
: \\
: \\
: \\
: \\
: \\
: \\
: \\
: \\
: \\
\text { A }\end{array}$ & $\begin{array}{l}A \\
\text { R } \\
\text { A } \\
\text { A } \\
\text { A } \\
\text { C } \\
\text { F } \\
\text { V } \\
\text { A } \\
\text { F } \\
\text { R } \\
\text { C } \\
\text { A } \\
\text { V } \\
\text { V } \\
\text { V } \\
\text { V } \\
\text { V } \\
\text { V } \\
\text { V } \\
\text { V } \\
\text { A } \\
\text { A }\end{array}$ & $\begin{array}{l}\text { A } \\
\text { A } \\
\text { A } \\
\text { A } \\
\text { C } \\
\text { V } \\
\text { V } \\
\text { A } \\
\text { C } \\
\text { C } \\
\text { A } \\
\text { A } \\
\text { C } \\
\text { A } \\
\text { A } \\
\text { A } \\
\text { A } \\
\text { A } \\
\text { A } \\
\text { A } \\
\text { A } \\
\text { A } \\
\text { A }\end{array}$ & 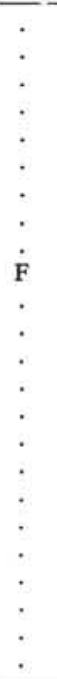 & $\begin{array}{l}\dot{ } \\
\vdots \\
\vdots \\
\dot{\mathrm{r}} \\
\dot{ } \\
\dot{ } \\
\dot{ }\end{array}$ \\
\hline 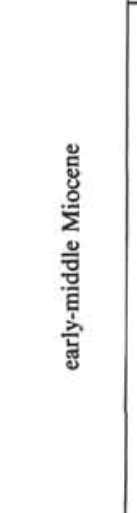 & $\int_{\mathrm{CN} 1}^{\mathrm{CN} 5 \mathrm{a}}$ & $\begin{array}{l}7 \mathrm{H}-3,110-111 \\
7 \mathrm{H}-4,110-111 \\
7 \mathrm{H}-5,110-111 \\
7 \mathrm{H}-6,110-111 \\
7 \mathrm{H}-\mathrm{CC} \\
8 \mathrm{H}-1,110-111 \\
8 \mathrm{H}-2,110-111 \\
8 \mathrm{H}-4,110-111 \\
8 \mathrm{H}-5,110-111 \\
8 \mathrm{H}-6,110-111 \\
8 \mathrm{H}-\mathrm{CC} \\
9 \mathrm{H}-1,118-119 \\
9 \mathrm{H}-2,118-119 \\
9 \mathrm{H}-3,118-119 \\
9 \mathrm{H}-4,118-119 \\
9 \mathrm{H}-5,118-119 \\
9 \mathrm{H}-6,118-119 \\
9 \mathrm{H}-\mathrm{CC}\end{array}$ & $\begin{array}{l}\text { A } \\
\text { A } \\
\text { A } \\
\text { A } \\
\text { A } \\
\text { A } \\
\text { A } \\
\text { A } \\
\text { A } \\
\text { A } \\
\text { A } \\
\text { A } \\
\text { A } \\
\text { A } \\
\text { A } \\
\text { A } \\
\text { A } \\
\text { A }\end{array}$ & $\begin{array}{l}\text { G } \\
\text { G } \\
\text { G } \\
\text { G } \\
\text { G } \\
\text { M } \\
\text { M } \\
\text { G } \\
\text { G } \\
\text { G } \\
\text { G } \\
\text { G } \\
\text { G } \\
\text { G } \\
\text { M } \\
\text { G } \\
\text { G } \\
\text { G }\end{array}$ & $\begin{array}{l}\mathrm{R} \\
\mathrm{C} \\
\mathrm{C} \\
\mathrm{F} \\
\mathrm{R} \\
\dot{\mathrm{R}} \\
\mathrm{R} \\
\mathrm{F} \\
\mathrm{C} \\
\mathrm{R} \\
\mathrm{R} \\
\mathrm{F} \\
\mathrm{F} \\
\mathrm{F} \\
\mathrm{R} \\
\mathrm{F} \\
\text {. }\end{array}$ & $\begin{array}{l}\mathrm{R} \\
\mathrm{F} \\
\dot{\mathrm{F}} \\
\dot{\mathrm{R}} \\
\mathrm{R} \\
\mathrm{R} \\
\mathrm{F} \\
\mathrm{C} \\
\mathrm{R} \\
\mathrm{R} \\
\dot{.} \\
\dot{.} \\
\dot{\mathrm{R}} \\
\mathrm{F} \\
.\end{array}$ & $\begin{array}{l}\mathrm{r} \\
\mathrm{r} \\
\mathrm{r} \\
\mathrm{r} \\
\mathrm{r} \\
\mathrm{r} \\
\mathrm{r} \\
\mathrm{r} \\
\mathrm{r} \\
\mathrm{r} \\
\mathrm{r} \\
\mathrm{r} \\
\mathrm{r} \\
\mathrm{r} \\
\mathrm{r} \\
\mathrm{r} \\
\mathrm{r} \\
\mathrm{r}\end{array}$ & $\begin{array}{l}\text { C } \\
\text { V } \\
\text { V } \\
\text { A } \\
\text { A } \\
\text { A } \\
\text { V } \\
\text { A } \\
\text { A } \\
\text { A } \\
\text { V } \\
\text { C } \\
\text { A } \\
\text { A } \\
\text { A } \\
\text { A } \\
\text { A } \\
\text { A }\end{array}$ & 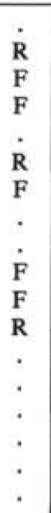 & 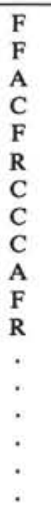 & $\begin{array}{l}\dot{\mathrm{F}} \\
\dot{\mathrm{R}} \\
\dot{2} \\
\dot{\mathrm{R}} \\
\mathrm{R} \\
\dot{\mathrm{F}} \\
\mathrm{C} \\
\dot{.} \\
\dot{\mathrm{R}} \\
\dot{\mathrm{R}} \\
\dot{ }\end{array}$ & $\begin{array}{l}\dot{.} \\
\dot{5} \\
\dot{5} \\
\dot{.} \\
\dot{.} \\
\dot{.} \\
\dot{.}\end{array}$ & $\begin{array}{l}\dot{ } \\
\dot{:} \\
\dot{.} \\
\dot{\mathrm{R}} \\
\dot{.} \\
\dot{\mathrm{C}} \\
\dot{\mathrm{F}} \\
\mathrm{F} \\
\dot{ } \\
\dot{ }\end{array}$ & $\begin{array}{l}\text { F } \\
\text { F } \\
\text { C } \\
\text { V } \\
\text { A } \\
\text { R } \\
\text { C } \\
\text { F } \\
\text { C } \\
\text { C } \\
\text { V } \\
\text { A } \\
\text { A } \\
\text { A } \\
\text { V } \\
\text { V } \\
\text { A }\end{array}$ & 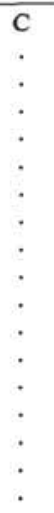 & 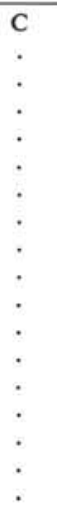 & 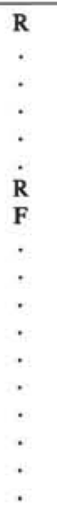 & 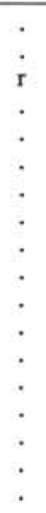 \\
\hline
\end{tabular}

Note: Abundance is characterized by V, very abundant; A, abundant, C, common; F, few; R, Rare; B, barren. For preservation, G, good; M, moderate; P, poor. Lower case letters indicate material considered to be reworked.

Floras dominated by Reticulofenestra perplexa and/or other Reticulofenestra species constitute the southernmost assemblages and represent colder waters, whereas assemblages dominated by C. pelagicus represent somewhat warmer waters. Quantitative study of $S$. perplexa/R. producta vs. $C$. pelagicus and biometric study of $S$. perplexa/R. producta are presented in Wei and Wise (in press).

The highest level of Cyclicargolithus floridanus was found in Sample 119-744B-7H-3, 110-111 cm. This sample through Sample 119-744B-9H-CC, is assigned to Zones CN1-5a based on the presence of $C$. floridanus and the absence of Reticulofenestra bisecta.

\section{Site 746}

All 16 core-catcher samples from the recovered siliceous ooze sequence at Site $\mathbf{7 4 6}$ are barren of calcareous nannofossils. The only nannofossiliferous sample from this site is Sample 119$746 \mathrm{~A}-13 \mathrm{X}-4,36 \mathrm{~cm}$. It contains abundant, strongly etched $R e-$ ticulofenestra perplexa and common Coccolithus pelagicus, which are indicative of middle-late Miocene age.

\section{PRYDZ BAY SITES}

Prydz Bay was chosen for drilling by Leg 119 because it is a major drainage system outlet on the Antarctic continent, and 
therefore should provide the best chance of recording all stages of Antarctic glaciation and a record of the preglacial continental climate. Holes were drilled along a profile between $66^{\circ} 55^{\prime} \mathrm{S}$ and $68^{\circ} 41^{\prime} \mathrm{S}$, at four sites $(739,740,741$, and 742$)$ on the shelf and one (743) on the continental slope (Fig. 1).

\section{Site 739}

Nearly $500 \mathrm{~m}$ of sediment were drilled at this site, but the core-recovery rate is low $(\mathbf{3 4 . 6 \% )}$ ). The sequence recovered is mostly diamictite. Calcareous nannofossils are rare and sporadic but generally well preserved in the sediments. Because the sequence is dominated by diamictite, the calcareous nannofossils present may have undergone redeposition to various extent. Consequently, the reliability of the biostratigraphy for these sediments should be considered low.

Sample 119-739C-2X-CC contains about a dozen calcareous nannofossil species (Table 8), mostly of Eocene age, but diatoms present suggest a Quaternary age for this level (Baldauf and Barron, this volume); therefore, the calcareous nannofossil species are reworked. The relatively diverse Eocene species may indicate relatively rich carbonate deposition in or near Prydz Bay sometime during the Eocene, and suggest significantly warmer temperatures than at present.

Sample 119-739C-8R-CC yielded 14 calcareous nannofossil species, including two Cretaceous species (Arkhangelskiella cymbiformis and Cribrosphaerella ehrenbergii). This sample and Sample 119-739C-13R-CC contain Reticulofenestra producta, a middle Miocene-Pliocene species and the youngest nannofossil ever found on the Antarctic continental margin. Two specimens of Reticulofenestra reticulata were found in Sample 119-739C$22 \mathrm{R}-2,12-14 \mathrm{~cm}$. All these nannofossils, except for Coccolithus pelagicus, Reticulofenestra perplexa, and $R$. producta, must be reworked.

Isthmolithus recurvus was found in Samples 119-739C-28R-1, $30-32 \mathrm{~cm}$, and $-30 \mathrm{R}-1,108-110 \mathrm{~cm}$, along with one or several Eocene-Oligocene nannofossil species. Isthmolithus recurvus is known to range from 35 to $39 \mathrm{Ma}$ in middle and high latitudes (Wei and Wise, 1989a, 1990). Other species present in these two samples are consistent with this age range. The nannofossil assemblages are also comparable to those of late Eocene-early Oligocene intervals from the Kerguelen Plateau, Maud Rise in the Weddell Sea (Wei and Wise, 1990), and the CIROS-1 drill core in the Ross Sea (Edwards and Waghorn, 1989). Similarly, Baldauf and Barron (this volume) found that diatom assemblages present in this interval are comparable to those from the Kerguelen Plateau and the CIROS-1 drill core, and they argue for in situ early Oligocene diatoms in this interval. However, strontium isotope analyses of bivalve and scaphopod fragments from Core 119-739C-25R, -29R, -31R, -33R, -34R, and $-36 R$ suggest that Cores $119-739 \mathrm{C}-31 \mathrm{R}$ through $-36 \mathrm{R}$ represent a nearcontinuous sediment deposition from 23.4 to $29.25 \mathrm{Ma}$ and that the fossil fragments from Cores 119-739C-25R through -29R are reworked (Macdougall et al., this volume). A comparison of the results of calcareous nannofossils, diatoms, and strontium isotopic stratigraphy are summarized in Figure 5. If the strontium isotopic ages are correct, both the calcareous nannofossils and the diatoms would be considered reworked.

A few specimens of Reticulofenestra umbilica were found in Samples 119-739C-36R-2, 142-143 cm, and -38R-1, 35-37 cm. Reticulofenestra umbilica ranges from middle Eocene to early Oligocene age. Reticulofenestra daviesii is the most abundant and consistently present taxon in Hole 739C and occurs down to Sample $119-739$ C-46R-1, $123-125 \mathrm{~cm}$, at $376.5 \mathrm{mbsf}$. This species prefers cool/cold waters and ranges from middle Eocene to latest Oligocene age at high latitudes. It is not certain whether or not all these nannofossils are reworked, but they restrict the age to middle Eocene or younger for samples down to $377 \mathrm{mbsf}$.
In addition, Reticulofenestra reticulata, which is abundant in the upper Eocene sediments on Kerguelen Plateau and at other high-latitude sites, was not found in Sample 119-739C-38R-1, $35-37 \mathrm{~cm}$, which contains a relatively diverse assemblage. This negative evidence may suggest that the sample is late Eocene or younger.

Information from Site 739 has extended the known biogeographic ranges of the following species to the Antarctic margin: Arkhangelskiella cymbiformis, Chiasmolithus altus, Chiasmolithus oamaruensis, Coccolithus formosus, Coccolithus pelagicus, Cribrosphaerella ehrenbergii, Cyclicargolithus floridanus, Isthmolithus recurvus, Neococcolithes dubius, Reticulofenestra bisecta, Reticulofenestra daviesii, Reticulofenestra hesslandii, Reticulofenestra hillae, Reticulofenestra perplexa, Reticulofenestra producta, Reticulofenestra reticulata, Reticulofenestra samodurovii, Reticulofenestra umbilica, and Zygrhablithus bijugatus.

\section{Sites 740-743}

All the core-catcher samples from Sites 740, -741, and -743 are barren of calcareous nannofossils. Only three of the core-catcher samples from Site 742 contained calcareous nannofossils. Sample 119-742A-10R-CC yielded Chiasmolithus altus, Coccolithus formosus, and Reticulofenestra daviesii. Sample 119-742A-11R-CC contained rare Chiasmolithus altus, Chiasmolithus expansus, Coccolithus pelagicus, Cyclicargolithus floridanus, Reticulofenestra reticulata, Reticulofenestra samodurovii, Reticulofenestra umbilica, and Sphenolithus moriformis. Rare specimens of Reticulofenestra reticulata were found in Sample 119-742A-13R-CC. The assemblages in these samples may indicate a middle to upper Eocene age, but are most likely reworked, because diatom data suggest a Pliocene age for this interval (Barron et al., 1989). Sample 119-742A-27R-5, $13 \mathrm{~cm}$ (246 mbsf), taken next to a pelecypod shell yielded rare but well preserved Reticulofenestra daviesii, a species of middle Eocene to late Oligocene age. Seismic stratigraphic data (Barron, Larsen, et al., 1989) suggest that this is the oldest glacial marine sequence drilled in Prydz Bay.

\section{SUMMARY AND CONCLUSIONS}

Recovery of relatively continuous calcareous sequences of lower Turonian through Miocene by Leg 119 makes it possible to extend the study of calcareous nannofossil biostratigraphy, biogeography, and paleoecology to the Indian Ocean sector of the Southern Ocean. The present study has established nannofossil biostratigraphy for these materials; nannofossil datums useful for constructing age-depth curves (see synthesis paper by Barron et al., this volume) are summarized in Table 9. This study has also provided semiquantitative data on the distribution of calcareous nannofossil assemblages.

Upper Cretaceous nannofossil assemblages from the Kerguelen Plateau have relatively low species diversity, partly due to poor preservation. The compositions of the assemblages, however, are comparable to those at other high-latitude sites. The assemblages are dominated by high-latitude taxa, such as Nephrolithus frequens, Arkhangelskiella cymbiformis, Kamptnerius magnificus, and Lucianorhabdus cayeuxii. Low-latitude taxa, such as Watznaueria barnesae and Micula murus are rare or absent.

After the Cretaceous/Tertiary boundary extinction event, only a few species occurred during the first million years. Some taxa reported common or abundant in low or middle latitudes (e.g., Braarudosphaera, Biscutum parvulum, Biscutum romeinii, and Toweius petalosus) are very rare or absent at Site 738 on the southern Kerguelen Plateau. Thoracosphaera are less abundant than at lower latitudes and no acme of this taxon was found at Site 738. On the other hand, abundant Hornibrookina teuriensis are present in Subzone CP1b at Site 738. Previously, Horni- 


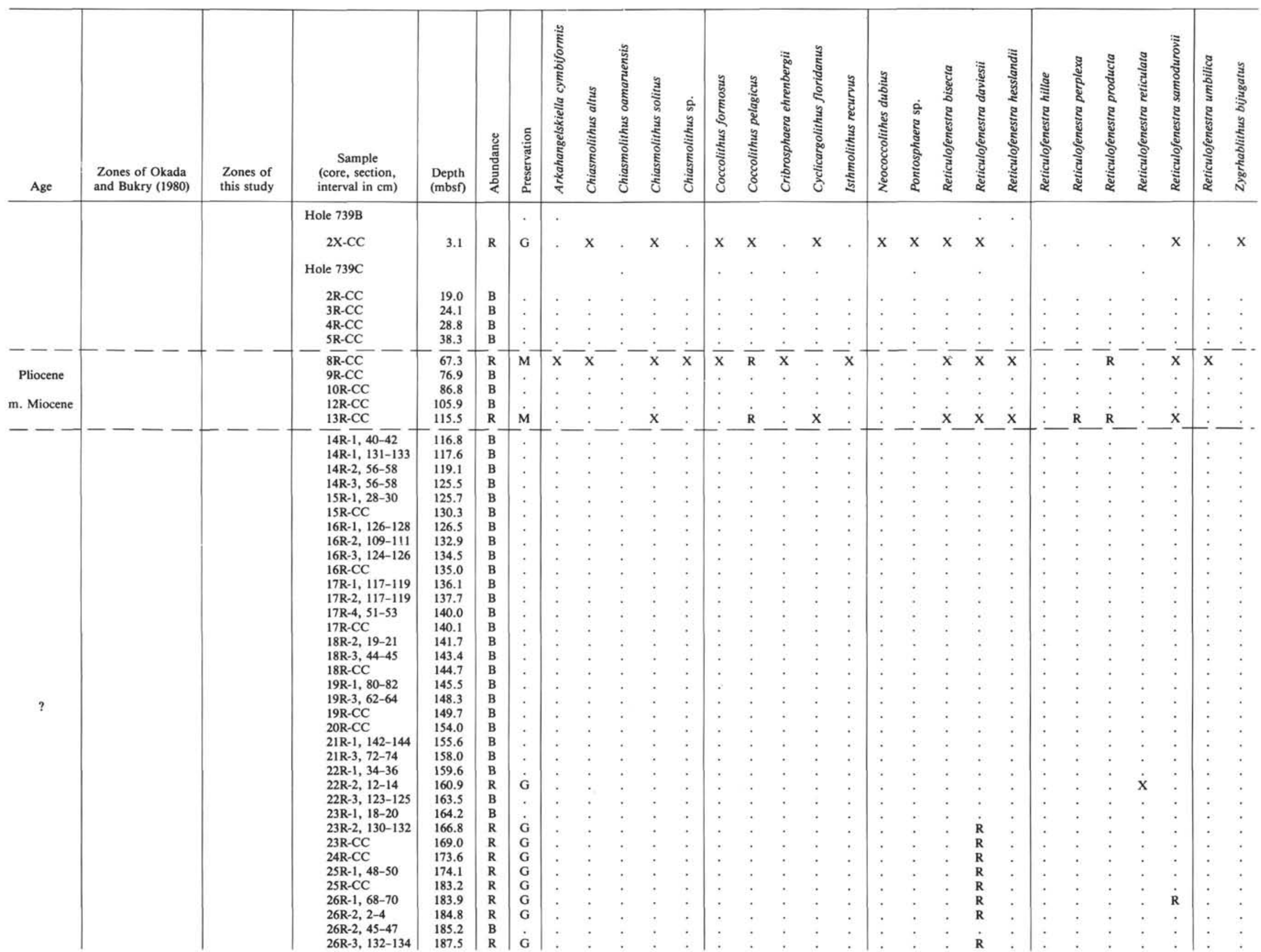




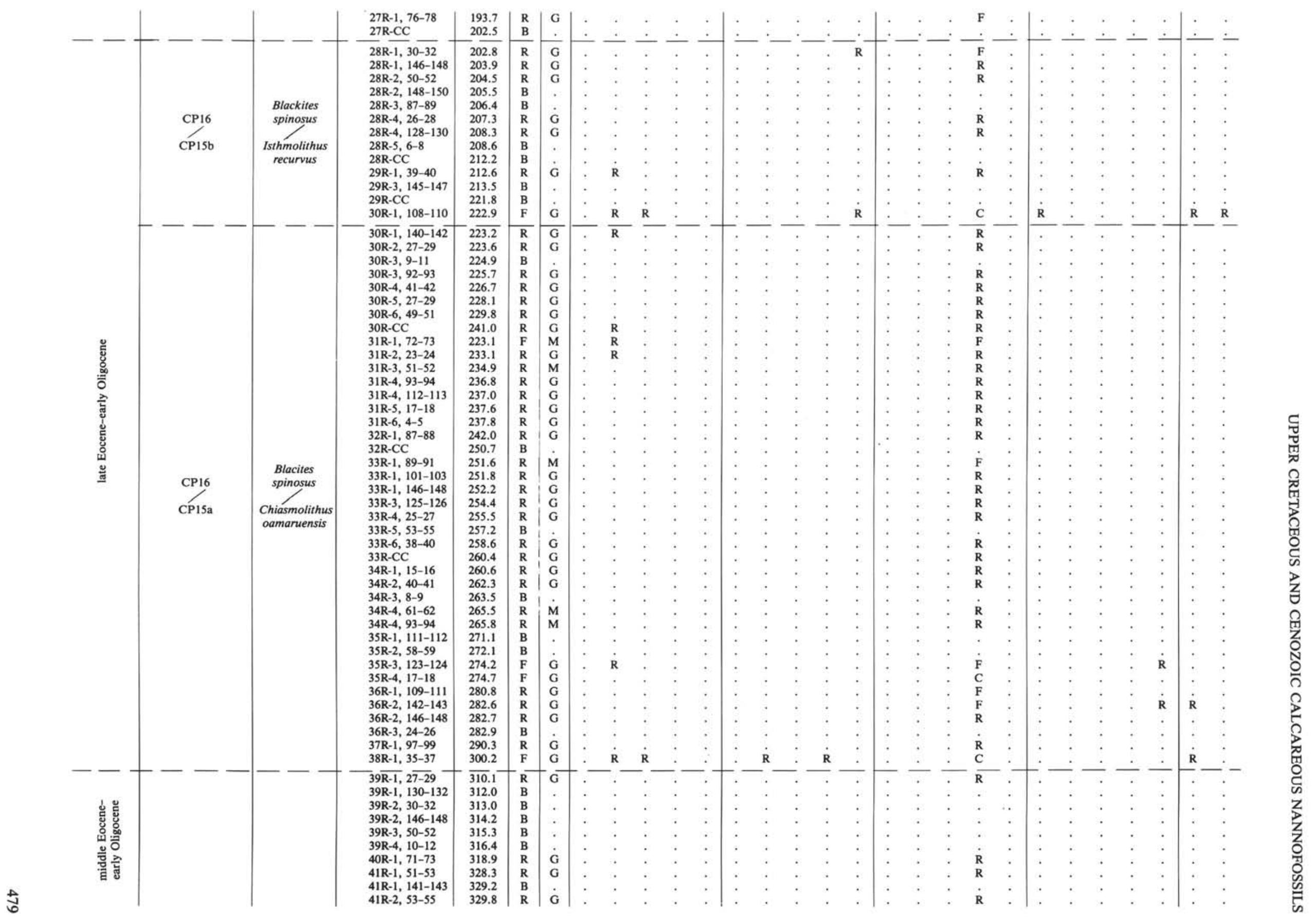


Table 8 (continued).

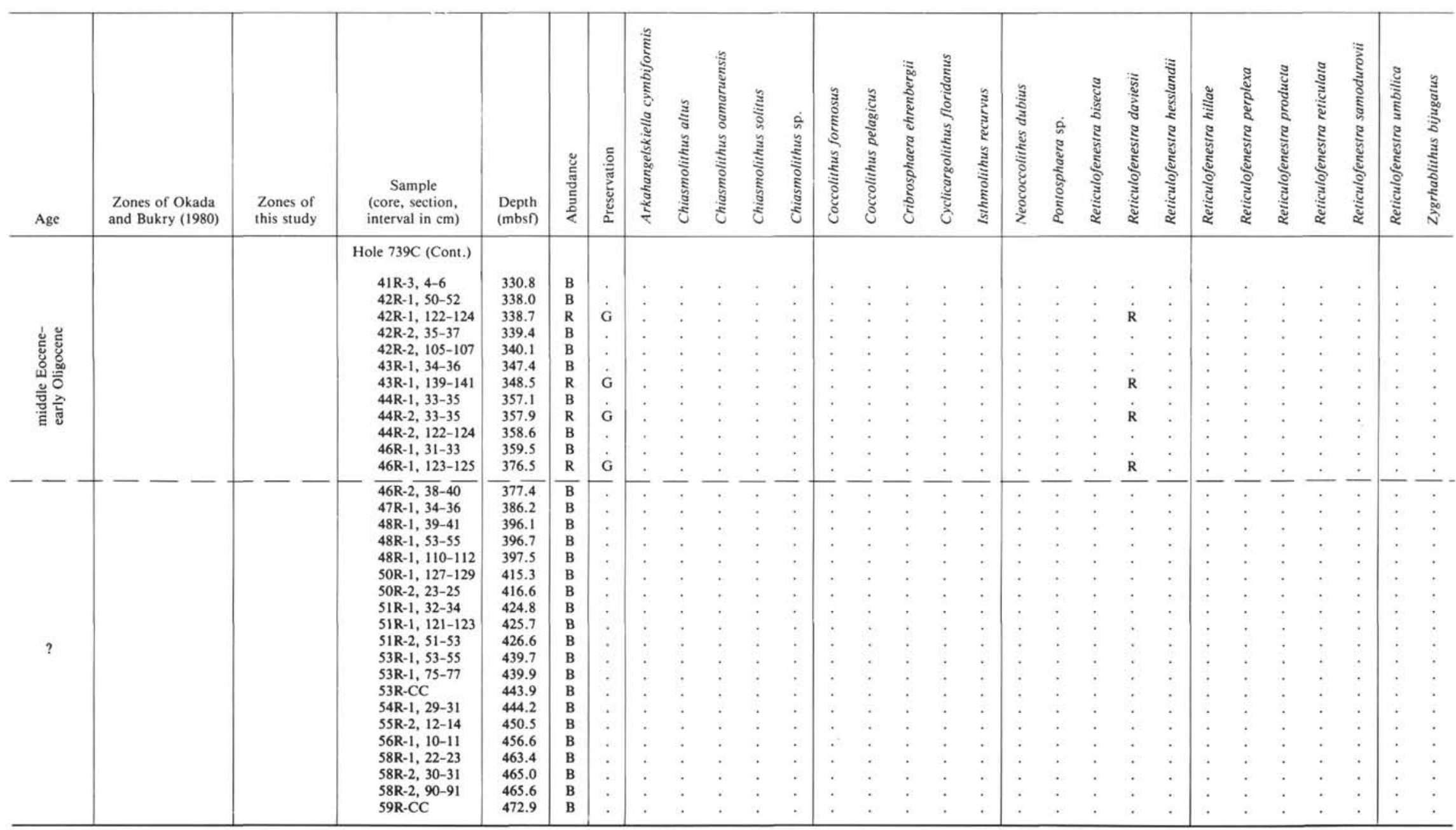

Note: Abundance is characterized by C, common; F, few; R, rare; B, barren. For preservation, G, good; M, moderate. $\mathrm{X}$ indicates material reworked. 


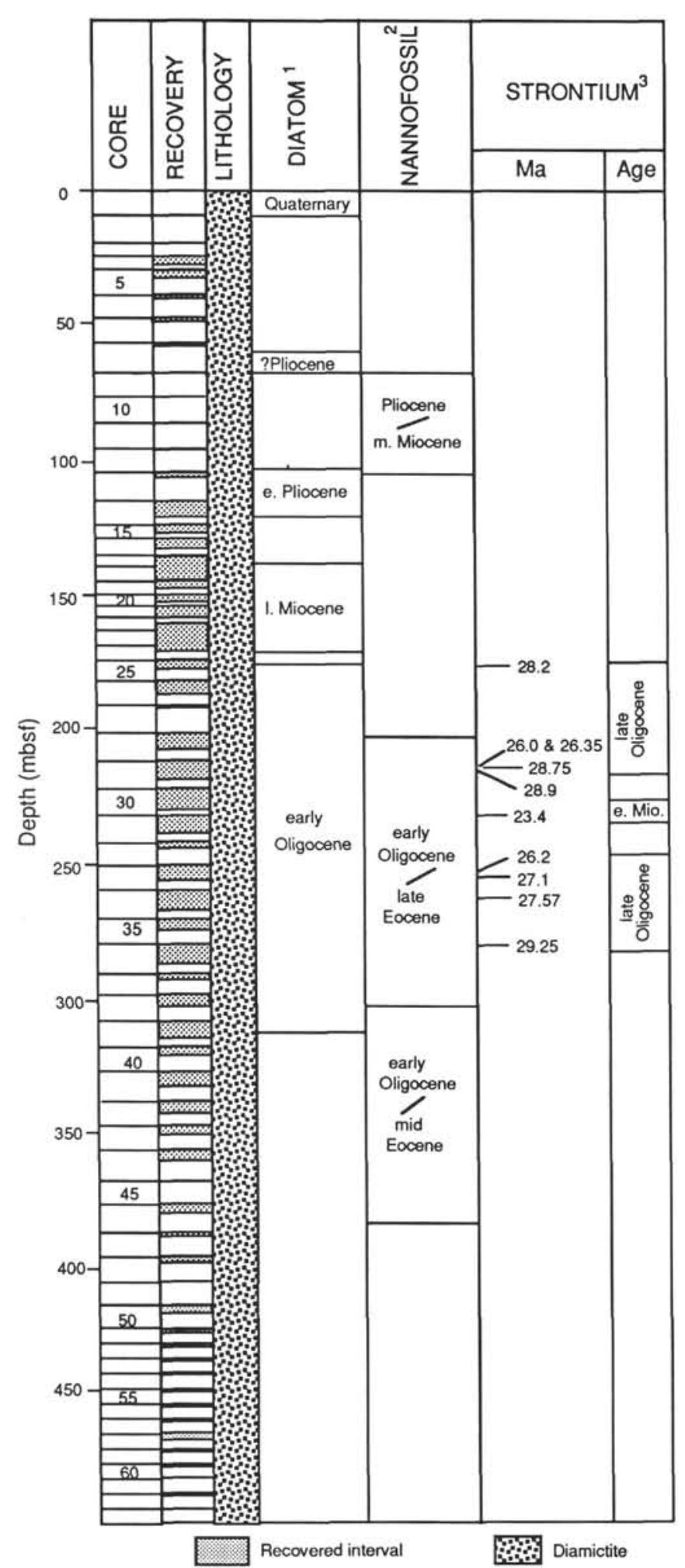

Figure 5. Summary of litho- and biostratigraphy of Site 739 and strontium isotopic dates of bivalves and scaphopod fragments from selected samples. Data are taken from Baldauf and Barron (this volume) for diatom biostratigraphy, this study for nannofossil biostratigraphy, and Macdougall et al. (this volume) for strontium isotopic dates. brookina teuriensis and/or Hornibrookina edwardsii have been reported from the southwest Pacific (Edwards, 1973), the South Atlantic (Perch-Nielsen, 1977), Texas, U.S.A. (Jiang and Gartner, 1986), Argentina (Angelozzi, 1988), the North Sea (Varol, 1989), and the Weddell Sea (Pospichal and Wise, 1990b). These species are never abundant in any of these localities except in the Weddell Sea. The early Paleocene assemblages at Site 738 are distinctly different from those of the middle- and low-latitude sites but are quite similar to those found in the Weddell Sea. A latitudinal differentiation of calcareous nannofossils appears to exist between the southern high latitudes and the middle or low latitudes in the earliest Paleocene (see detailed discussion of the early Paleogene calcareous nannofossils by Wei and Pospichal, this volume).

In the upper Paleocene, Chiasmolithus bidens, Prinsius martinii, and Toweius callosus are abundant on the southern Kerguelen Plateau, whereas these species are few or rare in low-latitude areas. On the other hand, Discoaster nobilis is virtually absent, Heliolithus species are rare and sporadic, and Sphenolithus primus is less abundant and occurs later than Fasciculithus tympaniformis at Site 738. All these suggest significantly cooler water temperatures at Site 738 than at the middle- or low-latitude sites during the late Paleocene.

Large chiasmoliths (i.e., Chiasmolithus expansus, Chiasmolithus grandis, and Chiasmolithus gigas) are considerably fewer at this high-latitude site than in the temperate regions. It appears that cool or cold waters were not favorable for large chiasmoliths, whereas smaller chiasmoliths (e.g., Chiasmolithus solitus and $C$. altus) flourished in the relatively cold waters. This kind of size-temperature relationship has been noted previously for other genera of calcareous nannoplankton, such as Discoaster (Bukry, 1971). Though the abundance of Discoaster is generally low, most of the stratigraphically important Discoaster species are present in the Eocene sections from the Kerguelen Plateau. This may reflect warmer water temperatures for the Eocene than for other periods of the Cenozoic, as suggested by oxygen isotopic data (Shackleton and Kennett, 1975; Shackleton, 1986; Miller et al., 1987). By the end of the Eocene, virtually all discoasters disappeared from Kerguelen Plateau. Chiasmolithus altus and Reticulofenestra daviesii dominate the assemblages. These two species are known to prefer cool or cold waters.

Calcareous nannofossil species diversity is significantly lower in the Oligocene, during which time a few species disappeared, and virtually no new species appeared on Kerguelen Plateau. This is also reflected in the zonation scheme used where all the zones have to be defined by the last occurrences of calcareous nannofossil species.

Only a few calcareous nannofossil species were recorded in the Miocene sequences from the Kerguelen Plateau; the most important species include Coccolithus pelagicus and several species of Reticulofenestra. As in the Falkland Plateau region (Haq, 1980; Wise, 1983) and the Weddell Sea (Wei and Wise, 1990), Coccolithus pelagicus and one or two species of Reticulofenestra in the Miocene Kerguelen Plateau sequences exhibit extreme fluctuations in assemblage dominance. This may reflect sharp fluctuations of the surface-water temperatures in the Miocene, with intervals dominated by $C$. pelagicus representing warmer events and intervals dominated by Reticulofenestra species representing colder periods.

The upper Neogene sequences on Kerguelen Plateau are essentially devoid of calcareous nannofossils. When nannofloras were found, they usually consisted of monospecific assemblages of Reticulofenestra producta, a high-latitude species. Continuous deterioration of Neogene climate in the high latitudes and the expansion of the Antarctic surface water mass essentially drove out calcareous nannoplankton. However, a few early-middle Pleistocene species of calcareous nannofossils were found on 
Table 9. Calcareous nannofossil datum levels and estimated ages.

\begin{tabular}{|c|c|c|c|c|}
\hline Species events & Sample & Depth (m) & mid-point & Age* $^{*}(\mathrm{Ma})$ \\
\hline \multicolumn{5}{|l|}{ Hole 737B } \\
\hline LO Chiasmolithus altus & $11 \mathrm{R}-1,50 / 11 \mathrm{R}-2,80$ & $312.0 / 313.80$ & 312.90 & $a_{25.5}$ \\
\hline LO Reticulofenestra umbilica & $34 \mathrm{R}-\mathrm{CC} / 35 \mathrm{R}-\mathrm{CC}$ & $543.30 / 552.90$ & 548.10 & $\mathrm{a}_{32.2}$ \\
\hline LO Isthmolithus recurvus & $37 \mathrm{R}-4,45 / 37 \mathrm{R}-5,45$ & $567.45 / 568.95$ & 568.20 & $\mathrm{a}_{34.8}$ \\
\hline LO Discoaster saipanensis & $41 \mathrm{R}-1,91 / 41 \mathrm{R}-2,102$ & $602.01 / 603.62$ & 602.80 & $\mathrm{a}_{36.4}$ \\
\hline FO Reticulofenestra oamaruensis & $41 \mathrm{R}-3,132 / 41 \mathrm{R}-4,40$ & $605.42 / 605.99$ & 605.71 & $\mathrm{a}_{38.0}$ \\
\hline FO Isthmolithus recurvus & $46 \mathrm{R}-1,1 / 46 \mathrm{R}-1,90$ & $649.30 / 650.20$ & 649.75 & $\mathrm{a}_{38.3}$ \\
\hline FO Chiasmolithus oamaruensis & $46 \mathrm{R}-2,21 / 46 \mathrm{R}-\mathrm{CC}$ & $651.01 / 658.60$ & 654.81 & $\mathrm{a}_{41.0}$ \\
\hline LO Chiasmolithus solitus & $48 \mathrm{R}-3,46 / 48 \mathrm{R}-\mathrm{CC}$ & $671.36 / 677.60$ & 674.48 & $\mathrm{a}_{41.4}$ \\
\hline FO Reticulofenestra reticulata & 49R-CC/50R-1, 57 & $686.50 / 687.07$ & 686.79 & ${ }^{\mathrm{a}} 42.1$ \\
\hline \multicolumn{5}{|l|}{ Hole 738B } \\
\hline LO Reticulofenestra oamaruensis & $4 \mathrm{H}-1,66 / 4 \mathrm{H}-2,66$ & $23.66 / 25.16$ & 24.41 & $\mathrm{a}_{36.0}$ \\
\hline FO Reticulofenestra oamaruensis & $5 \mathrm{H}-2,66 / 5 \mathrm{H}-3,66$ & $34.66 / 36.16$ & 35.41 & $\mathrm{a}_{38.0}$ \\
\hline FO Isthmolithus recurvus & $5 \mathrm{H}-5,110 / 5 \mathrm{H}-6,66$ & $39.16 / 40.66$ & 39.91 & $\mathrm{a}_{38.8}$ \\
\hline FO Chiasmolithus oamaruensis & $8 \mathrm{R}-\mathrm{CC} / 9 \mathrm{H}-1,66$ & $70.50 / 71.16$ & 70.83 & $a_{41.0}$ \\
\hline FO Chiasmolithus solitus & $8 \mathrm{R}-\mathrm{CC} / 9 \mathrm{H}-1,66$ & $70.50 / 71.16$ & 70.83 & $a_{41.4}$ \\
\hline FO Reticulofenestra reticulata & $12 \mathrm{H}-2,66 / 12 \mathrm{H}-3,66$ & $96.66 / 98.16$ & 97.41 & $a_{42.1}$ \\
\hline FO Reticulofenestra umbilica & $15 X-1,66 / 15 X-2,66$ & $118.46 / 119.96$ & 119.21 & $a_{44.6}$ \\
\hline FO Nannotetrina fulgens & $23 \mathrm{X}-\mathrm{CC} / 24 \mathrm{X}-1,66$ & $204.60 / 205.26$ & 204.93 & $\mathrm{~b}_{49.8}$ \\
\hline \multicolumn{5}{|l|}{ Hole $738 \mathrm{C}$} \\
\hline FO Discoaster sublodoensis & $5 \mathrm{R}-1,69 / 5 \mathrm{R}-2,69$ & $226.26 / 227.79$ & 227.03 & $\mathrm{c}_{52.6}$ \\
\hline FO Discoaster lodoensis & $8 \mathrm{R}-\mathrm{CC} / 9 \mathrm{R}-1,66$ & $264.10 / 264.76$ & 264.43 & $c_{55.4}$ \\
\hline FO Discoaster diastypus & $10 \mathrm{R}-\mathrm{CC} / 11 \mathrm{R}-1,90$ & $283.40 / 284.30$ & 283.85 & $\mathrm{~d}_{56.7}$ \\
\hline FO Discoaster multiradiatus & $11 \mathrm{R}-\mathrm{CC} / 13 \mathrm{R}-\mathrm{CC}$ & $293.0 / 312.30$ & 302.65 & $b_{59.2}$ \\
\hline FO Discoaster mohleri & $14 \mathrm{R}-\mathrm{CC} / 15 \mathrm{R}-\mathrm{CC}$ & $321.90 / 331.60$ & 326.75 & $\mathrm{~b}_{60.5}$ \\
\hline FO Heliolithus kleinpellii & 15R-CC/16R-5, 97 & $331.60 / 338.30$ & 334.95 & $b_{61.6}$ \\
\hline FO Chiasmolithus bidens & $18 \mathrm{R}-1,35 / 18 \mathrm{R}-1,85$ & $351.25 / 351.75$ & 351.50 & $\mathrm{~b}_{63.2}$ \\
\hline FO Prinsius martinii & $18 \mathrm{R}-\mathrm{CC} / 19 \mathrm{R}-1,35$ & $360.50 / 360.85$ & 360.68 & $\mathrm{~b}_{65.5}$ \\
\hline FO Chiasmolithus danicus & $19 \mathrm{R}-3,85 / 19 \mathrm{R}-3,135$ & $364.35 / 364.85$ & 364.60 & $\mathrm{e}_{65.8}$ \\
\hline FO Cruciplacolithus tenuis & $20 \mathrm{R}-5,2 / 20 \mathrm{R}-5,35$ & $376.22 / 376.55$ & 376.39 & $b_{65.9}$ \\
\hline FO Biantholithus sparsus & 20R-5, 84/20R-5, 95 & $377.04 / 377.16$ & 377.10 & ${ }^{\circ} 66.4$ \\
\hline FO Nephrolithus frequens & $24 \mathrm{R}-1,24 / 24 \mathrm{R}-2,64$ & $409.14 / 411.67$ & 410.09 & ${ }^{\mathrm{f}} 68.0$ \\
\hline FO Broinsonia parca & 30R-CC $/ 31 \mathrm{R}-1,77$ & $466.60 / 467.63$ & 467.12 & $f_{81.9}$ \\
\hline \multicolumn{5}{|l|}{ Hole $744 \mathrm{~A}$} \\
\hline LO Reticulofenestra bisecta & $11 \mathrm{H}-\mathrm{CC} / 12 \mathrm{H}-1,92$ & $99.2 / 101.12$ & 100.16 & $\mathrm{a}_{24.0}$ \\
\hline LO Chiasmolithus altus & $12 \mathrm{H}-5,92 / 12 \mathrm{H}-6,92$ & $106.12 / 107.62$ & 106.87 & $\mathrm{a}_{25.5}$ \\
\hline LO Reticulofenestra umbilica & $14 \mathrm{H}-6,75 / 14 \mathrm{H}-\mathrm{CC}$ & $126.45 / 127.70$ & 127.08 & $\mathrm{a}_{32.2}$ \\
\hline LO Isthmolithus recurvus & $15 \mathrm{H}-2,75 / 15 \mathrm{H}-3,75$ & $129.95 / 131.45$ & 130.70 & $\mathrm{a}_{34.8}$ \\
\hline LO Reticulofenestra oamaruensis & $17 \mathrm{H}-\mathrm{CC} / 18 \mathrm{H}-1,75$ & $147.60 / 148.35$ & 147.98 & $\mathrm{a}_{36.0}$ \\
\hline LO Discoaster saipanensis & $19 \mathrm{H}-3,75 / 19 \mathrm{H}-4,7$ & $160.86 / 162.35$ & 161.61 & $b_{36.4}$ \\
\hline FO Reticulofenestra oamaruensis & $19 \mathrm{H}-\mathrm{CC} / 20 \mathrm{H}-1,75$ & $166.60 / 167.35$ & 166.97 & ${ }^{\mathrm{a}} 38.0$ \\
\hline FO Isthmolithus recurvus & $20 \mathrm{H}-2,75 / 20 \mathrm{H}-3,75$ & $168.85 / 170.35$ & 169.60 & ${ }^{\mathrm{a}} 38.8$ \\
\hline
\end{tabular}

the Kerguelen Plateau. This may suggest that during part of the early-middle Pleistocene surface waters on Kerguelen were significantly warmer than those of the present, because no calcareous nannoplankton have been reported from such a high latitude in the modern ocean.

Only rare and sporadic occurrences of calcareous nannofossils were found in the diamictite sequences recovered at Sites 739 and 742 in Prydz Bay. Cores 119-739C-28R and -30R yielded the most age-diagnostic calcareous nannofossil assemblages; the late Eocene-early Oligocene age (35-39 Ma) suggested by the nannofossil assemblages is consistent with the diatom age (Baldauf and Barron, this volume). Reticulofenestra daviesii is present down to Core 119-739C-46R (376 mbsf) and restricts the age to middle Eocene or younger for samples down to $376 \mathrm{mbsf}$.

\section{TAXONOMIC NOTES OF SELECTED SPECIES}

Clausicoccus fenestratus (Deflandre and Fert) Prins, 1979

$$
\text { (Pl. 4, Figs. 5, 6) }
$$

Discolithus fenestratus Deflandre and Fert, 1955, Ann. Paléont., vol. 40, p. 139, pl . 11, fig. 15.
Ellipsolithus subdistichus Roth and Hay, 1967, Trans. Gulf Coast. Ass. Geol. Soc., vol. 17, p. 446, pl. 6, fig. 7.

Ericsonia bireticulata Roth, 1970, Eclog. Geol. Helv. vol. 63, p. 840, pl. 1 , figs. 4,5 .

Ericsonia pauciperforata Roth, 1970, Eclog. Geol. Helv. vol. 63, p. 842, pl. 2 , fig. 1.

Ericsonia quadriperforata Roth, 1970, Eclog. Geol. Helv. vol. 63, p. 843 , pl. 2, fig. 2 .

Ericsonia subdisticha (Roth and Hay) Roth, Roth, 1970, Eclog. Geol. Helv. vol. 63 , p. 843 , pl. 2, figs. 3,4 .

Ericsonia obruta Perch-Nielsen, 1971, Kongl. Danske Vidensk. Selsk., Biol. Skr., vol. 18, p. 14, pl. 4, figs. 5, 6 .

Ericsonia fenestrata (Deflandre and Fert) Stradner, Perch-Nielsen, 1971, p. 12, pl. 5, figs. 1-6; pl. 6, figs. 6-11.

Ericsonia? cf. E. fenestrata, Perch-Nielsen, 1971, p. 13, pl. 6, figs. 1-5. Ericsonia? singularis Perch-Nielsen, 1971, p. 15, pl. 7, figs. 1-3, 5.

Clausicoccus fenestratus (Deflandre and Fert) Prins, 1979, p. N-4, fig. 3.

Clausicoccus fenestratus (Deflandre and Fert) Prins, Wise, 1983, p. 516, pl. 1, figs. 8, 9 .

Remarks. Since the description of Discolithus fenestratus by Deflandre and Fert (1955), a number of species names have been intro- 
duced for forms with a different numbers of perforations in the central area relative to the holotype of $D$. fenestratus, which has 20 . According to Roth (1970), Ericsonia bireticulata has two superimposed grills, Ericsonia pauciperforata has an irregular arrangement of the perforations in the central area, Ericsonia quadriperforata has 4 pores, and Ericsonia subdisticha has 10 pores. Ericsonia obruta Perch-Nielsen also has 4 pores, and Ericsonia? singularis Perch-Nielsen shows various numbers of pores up to 24 (Perch-Nielsen, 1971, pl. 7). However, examination of the literature reveals that the number of pores in the Clausicoccus fenestratus group varies in a seemingly continuous spectrum. This can be seen in the three plates (pls. 5-7) illustrated by Perch-Nielsen (1971), where the $C$. fenestratus group shows the following pore numbers: 7,7 , $8,9,9,11,13,13,15,15,18,18,19,19,20,20,21$, and 25 . The superimposed grills in E. bireticulata as described by Roth (1970) are not useful for species diagnosis either, because only one layer of grill can usually be seen. Other species of Clausicoccus may also possess two grills but only one has been seen. All species previously mentioned seem to have similar stratigraphic ranges (Eocene-Oligocene). Furthermore, it is difficult or impossible to count the pore numbers in a light microscope, especially when the specimens are less than perfectly preserved. Therefore, the species listed can be considered as junior synonyms of Clausicoccus fenestratus.

\section{Reticulofenestra gelida (Geitzenauer) Backman, 1979.}

$$
\text { (Pl. 1, Figs. 1-4) }
$$

Remarks. Backman (1980) analyzed and discussed the relationship between Reticulofenestra gelida and Reticulofenestra pseudoumbilica at length, concluding that the former is a winter morphovariant of the latter and that $R$. gelida is a junior synonym of $R$. pseudoumbilica. Reticulofenestra gelida is usually found in the high latitudes whereas $R$. pseudoumbilica is not, and the distribution patterns of these two species show no annual cycles. Thus, as has already been pointed out by Wise (1983), R. gelida should not be considered a winter morphotype of $R$. pseudoumbilica.

\section{Reticulofenestra perplexa (Burns) Wise, 1983.}

$$
\text { (PI. 1, Figs. 5-10) }
$$

Dictyococcites perplexa Burns, 1975, p. 594, figs. 13, 19-20.

Dictyococcites antarcticus Haq, 1976, p. 567, figs. 1-5, 7, 8.

Remarks. Backman (in Heck, 1981a, p. 40) was the first to point out that Dictyococcites antarcticus Haq (1976) is a junior synonym of Dictyococcites perplexa Burns (1975). Wise (1983, p. 505-506) remarks that "all of Burns's magnifications in his article are overstated by a factor of about 2.5. The dimensions he attributed the holotype of $D$. perplex $a$ are also overstated by the same factor; thus the holotype measures about 5 to $6 \mu \mathrm{m}$ along the length of the distal surface rather than $18-20 \mu \mathrm{m}$ as originally stated. The revised measurement is similar to those given by Haq (1976) for D. antarcticus (4 to $7 \mu \mathrm{m}$, rarely $8 \mu \mathrm{m}$ )." Wise (1983) transferred the species to Reticulofenestra. In spite of all this, there is still confusion in the literature. Recently, Driever (1988), based on a written communication with Burns in 1981 , claimed that $D$. perplexa has a size of $18-20 \mu \mathrm{m}$, and thus $D$. perplexa is different from $D$. antarcticus. Careful reexamination of Burns (1975) reveals that the magnifications in his figure captions are understated by a factor of $2-4$, whereas in the description of $D$. perplexa, the size of the species is overstated by a factor of about 3 . The correct size of $D$. perplexa should be 5-7 $\mu \mathrm{m}$, a similar size range as for $D$. antarcticus. Both $D$. perplexa and $D$. antarcticus have about 60 elements and a closed central area. The isotypes of Haq (1976) (his paratypes) are strongly etched specimens. By all recognized criteria, $D$. antarcticus is a junior synonym of $D$. perplexa.

Reticulofenestra perplexa has been found in high-latitude middle to upper Miocene sediments only. It is most abundant in high southern latitudes, where it constitutes nearly $100 \%$ of the nannofossil assemblage in many intervals (Wise, 1983; Wei and Wise, 1990; this study). Clearly, Reticulofenestra perplexa is a cold-water species that has special importance in paleoceanographic studies, as has been pointed out by Haq (1980, for his D. antarcticus).

Reticulofenestra producta (Kamptner) Wei and Thierstein, n. comb. (Pl. 1, Figs. 11 and 12)

Basionym. Ellipsoplacolithus productus Kamptner, 1963.

Dictyococcites productus (Kamptner) Backman, 1980.
Remarks. As pointed out by Wise (1983, p. 505), Dictyococcites is an ill-defined genus, and it is very difficult and of little profit to separate Dictyococcites from Reticulofenestra. Reticulofenestra producta has essentially the same structure as Reticulofenestra perplexa. The only difference is that $R$. producta is consistently smaller $(3-4 \mu \mathrm{m})$ than $R$. perplexa $(5-7 \mu \mathrm{m})$. It seems that $R$. producta grades into $R$. perplexa. However, $R$. perplexa is limited to the Miocene, whereas $R$. producta is found in both the Miocene and Pliocene, and the latter is the dominant species in high-latitude Pliocene nannofossil assemblages.

\section{ACKNOWLEDGMENTS}

We would like to thank our Leg 119 shipmates, especially John Barron, Birger Larsen (co-chief scientists), and Jack Baldauf (staff scientist), for their great efforts in making Leg 119 most successful and enjoyable. We also wish to thank Jack Baldauf, Sherwood Wise, and two anonymous reviewers for helpful reviews of this paper. This research was supported by grants from the U.S. Science Advisory Committee and a Florida State University Dissertation Fellowship to the first author. Support by the Swiss National Science Foundation to the second author is acknowledged.

\section{REFERENCES}

Angelozzi, G. N., 1988. Nannofossils paleoceneo del Noreste de la Cuenca Neuquina, Republica Argentina. Ameghiniana, 24:299-307.

Backman, J., 1980. Miocene-Pliocene nannofossils and sedimentation rates in the Hatton-Rockall Basin, NE Atlantic Ocean. Stockholm Contrib. Geol., 36:1-91.

Barron, J., Larsen, B., et al., 1989. Proc. ODP, Init. Repts., 119: College Station, TX (Ocean Drilling Program).

Berggren, W. A., Kent, D. V., and Flynn, J. J., 1985. Jurassic to Paleogene: Part 2. Paleogene geochronology and chronostratigraphy. In Snelling, N. J. (Ed.), The Chronology of the Geological Record: Geol. Soc. London Mem., 10:141-195.

Bralower, T. J., 1988. Calcareous nannofossil biostratigraphy of the Cenomanian-Turonian boundary interval and the origin and timing of oceanic anoxia. Mar. Micropaleontol., 3:275-316.

Bukry, D., 1971. Discoaster evolutionary trends. Micropaleontology, $17: 43-52$.

1973. Low-latitude coccolith biostratigraphic zonation. In Edgar, N. T., Saunders, J. B., et al., Init. Repts. DSDP, 15: Washington (U.S. Govt. Printing Office), 685-703.

Burns, D. A., 1975. Nannofossil biostratigraphy for Antarctic sediments, Leg 28, Deep Sea Drilling Project. In Hays, D. E., Frakes, L. A., et al., Init. Repts. DSDP, 28: Washington (U.S. Govt. Printing Office), 589-698.

Chave, A., 1984. Lower Paleocene-Upper Cretaceous magnetostratigraphy, Site 526, 527, 528, and 529, Deep Sea Drilling Project Leg 74. In Moore, T. C., Jr., Rabinowitz, P. D., et al., Init. Repts. DSDP, 74: Washington (U.S. Govt. Printing Office), 525-531.

Driever, B., 1988. The size of the coccoliths of Dictyococcites perplexa Burns. INA Newsl., 10:89.

Edwards, A. R., 1971. A calcareous nannoplankton zonation of the New Zealand Paleogene. In Farinacci, A. (Ed.), Proc. 2nd Planktonic Conf. Roma, 1:381-419.

1973. Calcareous nannofossils from the southwest Pacific. In Burns, R. E., Andrews, J. E., et al., Init. Repts. DSDP, 21: Washington (U.S. Govt. Printing Office), 641-691.

Edwards, A. R., and Perch-Nielsen, K., 1975. Calcareous nannofossils from the southern southwest Pacific, Deep Sea Drilling Project, Leg 29. In Kennett, J. P., Houtz, R. E., et al., Init. Repts. DSDP, 29: Washington (U.S. Govt. Printing Office), 469-539.

Edwards, A. R., and Waghorn, D. B., 1989. Calcareous nannofossils. In Barrett, P. J. (Ed.), Antarctic Cenozoic History from the CIROS-1 Drillhole, McMurdo Sound. DSIR Bulletin, 245:145-149.

Firth, J., 1989. Biometric study of Eocene-Oligocene calcareous nannofossils [Ph. D. dissert.]. Florida State Univ., Tallahassee.

Haq, B. U., 1976. Coccoliths in cores from the Bellingshausen abyssal plain and Antarctic continental rise (DSDP Leg 35). In Hollister, C. D., Craddock, C., et al., Init. Repts. DSDP, 35: Washington (U.S. Govt. Printing Office), 557-567. 
1980. Biogeographic history of Miocene calcareous nannoplankton and paleoceanography of the Atlantic Ocean. Micropale ontology, 26:414-443.

Haq, B. U., Lohmann, G. P., and Wise, S. W., 1977. Calcareous nannoplankton biogeography and its paleoclimatic implications: Cenozoic of the Falkland Plateau (DSDP Leg 36) and Miocene of the North Atlantic Ocean. In Barker, P. F., Dalziel, I.W.D., et al., Init. Repts. DSDP, 36: Washington (U.S. Govt. Printing Office), 745-759.

Jiang, M. J., and Gartner, S., 1986. Calcareous nannofossil succession across the Cretaceous/Tertiary boundary in east-central Texas. Micropaleontology, 32:232-255.

Loeblich, A. R., Jr., and Tappan, H., 1966. Annotated index and bibliography of the calcareous nannoplankton. Phycologia, 5:81-216.

1968. Annotated index and bibliography of the calcareous nannoplankton II. J. Paleontol., 42:584-598.

1969. Annotated index and bibliography of the calcareous nannoplankton III. J. Paleontol., 43:586-588.

$1970 \mathrm{a}$. Annotated index and bibliography of the calcareous nannoplankton IV. J. Paleontol., 44:558-574. , 1970b. Annotated index and bibliography of the calcareous nannoplankton V. Phycologia, 9:157-174. , 1971. Annotated index and bibliography of the calcareous nannoplankton VI. Phycologia, 10:315-339.

, 1973. Annotated index and bibliography of the calcareous nannoplankton VII. J. Paleontol. 47:715-759.

Manivit, H., 1984. Paleogene and Upper Cretaceous calcareous nannofossils from Deep Sea Drilling Project Leg 74. In Moore, T. C., Jr., Rabinowitz, P. D., et al., Init. Repts. DSDP, 74: Washington (U.S. Govt. Printing Office), 475-499.

Manivit, H., Perch-Nielsen, K., Prins, B., and Verbeek, J. W., 1977. Mid Cretaceous calcareous nannofossil biostratigraphy. Proc. $K$. Ned. Akad. Wet., Ser. B: Palaeontol., Geol., Phys., Chem., 8:169191.

Martini, E., 1971. Standard Tertiary and Quaternary calcareous nannoplankton zonation. In Farinacci, A. (Ed.), Proc. 2nd Planktonic Conf. Roma: Roma (Edizioni Technoscienza), 2:739-785.

Miller, K. G., Fairbank, R. G., and Mountain, G. S., 1987. Tertiary oxygen isotope synthesis, sea level history, and continental margin erosion. Paleoceanography, 2:1-19.

Monechi, S., Bleil, U., and Backman, J., 1985. Magnetobiochronology of Late Cretaceous-Paleogene and late Cenozoic pelagic sedimentary sequences from the northwest Pacific (Deep Sea Drilling Project, Leg 86, Site 577). In Heath, G. R., Burckle, L. H., et al., Init. Repts. DSDP, 86: Washington (U.S. Govt. Printing Office), 787-798.

Monechi, S,. and Thierstein, H.R., 1985. Late Cretaceous-Eocene nannofossil and magnetostratigraphic correlations near Gubbio, Italy. Mar. Micropaleontol., 9:419-440.

Okada, H., and Bukry, D., 1980. Supplementary modification and introduction of code numbers to the low-latitude coccolith biostratigraphic zonation (Bukry 1973; 1975). Mar. Micropaleontol., 5:321325 .

Perch-Nielsen, K., 1977. Albian to Pleistocene calcareous nannofossils from the western South Atlantic. In Perch-Nielsen, K., Supko, P. R., et al., Init. Repts. DSDP, 39: Washington (U.S. Govt. Printing Office), 699-823

1979. Calcareous nannofossils in Cretaceous/Tertiary boundary sections in Denmark. In Birkelund, T., and Bromley, R. G. (Eds.), Proc. Cretaceous-Tertiary Boundary Events Symp., Copenhagen, 1:120-126.

1985a. Cenozoic calcareous nannofossils. In Bolli, H. M., Saunders, J. B., and Perch-Nielsen, K. (Eds.), Plankton Stratigraphy: Cambridge (Cambridge Univ. Press), 427-554.

1985b. Mesozoic calcareous nannofossils. In Bolli, H. M. Saunders, J. B., and Perch-Nielsen, K. (Eds.), Plankton Stratigraphy: Cambridge (Cambridge Univ. Press), 329-426.

Perch-Nielsen, K., McKenzie, J. A., and He, Q., 1982. Biostratigraphy and isotope stratigraphy and the "catastrophic" extinction of calcareous nannoplankton at the Cretaceous/Tertiary boundary. Spec. Pap.-Geol. Soc. Am., 190:353-371.

Pospichal, J. J., and Wise, S. W., 1990a. Paleocene to middle Eocene calcareous nannofossils of ODP Sites 689 and 690, Maud Rise, Weddell Sea. In Barker, P. F., Kennett, J. P., et al., Proc. ODP, Sci. Results, 113: College Station, TX (Ocean Drilling Program), 613-638. 1990b. Calcareous nannofossils across the K/T Boundary, ODP Hole 690C, Maud Rise, Weddell Sea. In Barker, P. F., Kennett, J. P., et al., Proc. ODP, Sci. Results, 113: College Station, TX (Ocean Drilling Program) 515-532.

1990c. Maestrichtian calcareous nannofossil biostratigraphy of Maud Rise, ODP Leg 113 Sites 689 and 690, Weddell Sea. In Barker, P. F., Kennett, J. P., et al., Proc. ODP, Sci. Results, 113: College Station, TX (Ocean Drilling Program) 465-487.

Romein, A.J.T., 1979. Lineages in early Paleogene calcareous nannoplankton. Utrecht. Micropaleontol. Bull., 22:1-231.

Roth, P. H., 1973. Calcareous nannofossils-Leg 17, Deep Sea Drilling Project. In Winterer, E. L., Ewing, J. I., et al., Init. Repts. DSDP, 17: Washington (U.S. Government Printing Office), 695-795.

1978. Cretaceous nannoplankton biostratigraphy and oceanography of the northwestern Atlantic Ocean. In Benson, W. E., Sheridan, R. E., et al., Init. Repts. DSDP, 44: Washington (U.S. Government Printing Office), 731-761.

Roth, P. H., and Thierstein, H. R., 1972. Calcareous nannoplankton: Leg 14 of the Deep Sea Drilling Project. In Hayes, D. E., Pimm, A. C., et al., Init. Repts. DSDP, 14: Washington (U.S. Govt. Printing Office), 421-485.

Shackleton, N. J., 1986. Paleogene stable isotope events. Palaeogeogr., Palaeoclimat., Palaeoecol., 57:91-102.

Shackleton, N. J., and Kennett, J. P., 1975. Paleotemperature history of the Cenozoic and the initiation of Antarctic glaciation: oxygen and carbon isotope analyses in DSDP Sites 277, 279, and 281. In Kennett, J. P., Houtz, R. E., et al., Init. Repts. DSDP, 29: Washington (U.S. Govt. Printing Office), 743-755.

Shackleton, N. J., Moore, T. C., Jr., Rabinowitz, P. D., Boersma, A., Borella, P. E., Chave, A. D., Duee, G., Futterer, D., Jiang, M.-J., Kleinert, K., Lever, A., Manivit, H., O'Connell, S., and Richardson, S. H., 1984. Accumulation rates in Leg 74 sediments. In Moore, T. C., Jr., Rabinowitz, P. D., et al., Init. Repts, DSDP, 74: Washington (U.S. Govt. Printing Office), 621-637.

Steinmetz, J. C., 1985a. Bibliography and taxa of calcareous nannoplankton-V. INA Newsl., 7:5-28.

1985 b. Bibliography and taxa of calcareous nannoplanktonVI. INA Newsl., 7:122-145.

1986. Bibliography and taxa of calcareous nannoplanktonVIII. INA Newsl., 8:66-87.

1987a. Bibliography and taxa of calcareous nannoplanktonIX. INA Newsl., 9:6-29.

1987b. Bibliography and taxa of calcareous nannoplanktonX. INA Newsl., 10:81-109.

1988a. Bibliography and taxa of calcareous nannoplanktonXI. INA Newsl., 10:7-28.

, 1988b. Bibliography and taxa of calcareous nannoplanktonXII. INA Newsl., 10:60-88.

1989. Bibliography and taxa of calcareous nannoplanktonXIII. INA Newsl., 11:6-23.

Stradner, H., and Edwards, A. R., 1968. Electron microscopic studies on upper Eocene coccoliths from the Oamaru diatomite, New Zealand. Jahrb. Geol. Bundesanst., Austria, 13:1-66.

Stradner, H., and Steinmetz, J., 1984. Cretaceous calcareous nannofossils from the Angola Basin, Deep Sea Drilling Project Site 530. In Hay, W. W., Sibuet, J.-C., et al., Init. Repts. DSDP, 75: Washington (U.S. Govt. Printing Office), 565-649.

Thierstein, H. R., 1976. Mesozoic calcareous nannoplankton biostratigraphy of marine sediments. Mar. Micropaleontol., 1:325-362.

1981. Late Cretaceous nannoplankton and the change at the Cretaceous-Tertiary boundary. In Warme, J. E., et al. (Eds.), The Deep Sea Drilling Project: A Decade of Progress: Soc. Econ. Paleontol. Mineral., Spec. Publ., 32:355-394.

van Heck, S. E., 1979a. Bibliography and taxa of calcareous nannoplankton. INA Newsl., 1:AB1-B27.

1979b. Bibliography and taxa of calcareous nannoplankton. INA Newsl., 1:ABV1-B42.

1980a. Bibliography and taxa of calcareous nannoplankton. INA Newsl., 2:5-34.

1980b. Bibliography and taxa of calcareous nannoplankton.

INA Newsl., 2:43-81.

1981a. Bibliography and taxa of calcareous nannoplankton.

INA Newsl., 3:4-41. 
1981b. Bibliography and taxa of calcareous nannoplankton.

INA Newsl., 3:51-86.

1982a. Bibliography and taxa of calcareous nannoplankton.

INA Newsl., 4:7-50.

$1982 \mathrm{~b}$. Bibliography and taxa of calcareous nannoplankton.

INA Newsl., 4:65-96.

1983. Bibliography and taxa of calcareous nannoplankton.

INA Newsl., 5:4-13.

Varol, O., 1989. Paleocene calcareous nannofossil biostratigraphy. In Crux, J. A., and van Heck, S. E. (Eds.), Nannofossils and Their Applications: New York (Wiley), 267-310.

Wei, W., and Wise, S. W., 1989a. Paleogene calcareous nannofossil magnetobiochronology: results from South Atlantic DSDP Site 516. Mar. Micropaleontol., 14:119-152.

1989b. Discoaster praebifax n. sp.-A possible ancestor of Discoaster bifax Bukry (Coccolithophoridae). J. Paleontol., 63:10-14. 1990. Middle Eocene to Pleistocene calcareous nannofossils recovered by Ocean Drilling Program Leg 113 in the Weddell Sea. In Barker, P. F., Kennett, J. P., et al., Proc. ODP, Sci. Results, 113: College Station, TX (Ocean Drilling Program) 639-666.

, in press. Selected Neogene calcareous nannofossil species of the Southern Ocean: biochronology, biometrics, and paleoceanography. In Schlich, L., Wise, S. W., et al., Proc. ODP, Sci. Results, 120: College Station, TX (Ocean Drilling Program).

Wind, F. H., 1979a. Late Campanian and Maestrichtian calcareous nannoplankton biogeography and high-latitude biostratigraphy [Ph.D. dissert.]. Florida State Univ., Tallahassee.

1979b. Maastrichtian-Campanian nannoflora provinces of the southern Atlantic and Indian oceans. In Talwani, M., Hay, W. W., and Ryan, W.B.F. (Eds.), Deep Sea Drilling Results in the Atlantic Ocean: Continental Margins and Paleoenvironment: Am. Geophys. Union, Maurice Ewing Ser., 3:123-137.

Wise, S. W., Jr., 1983. Mesozoic and Cenozoic calcareous nannofossils recovered by Deep Sea Drilling Project Leg 71 in the Falkland Plateau region, Southwest Atlantic Ocean. In Lugwig, W. J., Krasheninnikov, V. A., et al Init. Repts. DSDP, 71: Washington (U.S. Govt. Printing Office), 481-550.

Wise, S. W., Jr., and Wind, F. H., 1977. Mesozoic and Cenozoic calcareous nannofossils recovered by DSDP Leg 36 drilling on the Falkland Plateau, Southwest Atlantic sector of the Southern Ocean. In Barker, P., Dalziel, I.W.D., et al., Init. Repts. DSDP, 36: Washington (U.S. Govt. Printing Office), 269-492.

Date of initial receipt: 4 October 1989

Date of acceptance: 11 April 1990

Ms 119B-165

\section{APPENDIX}

Calcareous Nannofossils Considered in This Paper

In alphabetical order of generic epithets (plate and figure numbers refer to illustrations in this paper).

\section{Cenozoic Species}

Biantholithus sparsus Bramlette and Martini, 1964

Bicolumnus ovatus Wei and Wise, 1990

Blackites spinosus (Deflandre and Fert) Hay and Towe, 1962

Braarudosphaera bigelowii (Gran and Braarud) Deflandre, 1974

Calcidiscus leptoporus (Murray and Blackman) Loeblich and Tappan, 1978. Pl. 3, Fig. 3

Calcidiscus macintyrei (Bukry and Bramlette) Loeblich and Tappan, 1978. Pl. 3, Figs. 1, 2

Chiasmolithus altus Bukry and Percival, 1971. Pl. 2, Fig. 11; Pl. 3, Fig. 4

Chiasmolithus bidens (Bramlette and Sullivan) Hay and Mohler, 1967

Chiasmolithus danicus (Brotzen) Hay and Mohler, 1967

Chiasmolithus expansus (Bramlette and Sullivan) Gartner, 1970. PI. 5, Fig. 10

Chiasmolithus gigas (Bramlette and Sullivan) Radomski, 1968

Chiasmolithus grandis (Bramlette and Sullivan) Radomski, 1978. Pl. 5, Fig. 11

Chiasmolithus oamaruensis (Deflandre) Hay, Mohler and Wade, 1966. Pl. 5, Fig. 9

Chiasmolithus solitus (Bramlette and Sullivan) Locker, 1968
Clausicoccus fenestratus (Deflandre and Fert) Prins, 1979. P1. 4, Figs. 5,6

Coccolithus formosus (Kamptner) Wise, 1973. Pl. 4, Figs. 14, 15

Coccolithus pelagicus (Wallich) Schiller, 1930

Cruciplacolithus edwardsii Romein, 1979

Cruciplacolithus primus Perch-Nielsen, 1977

Cruciplacolithus tenuis (Stradner) Hay and Mohler in Hay et al., 1967

Cyclicargolithus abisectus (Müller) Wise, 1973. Pl. 2, Fig. 10

Cyclicargolithus floridanus (Roth and Hay in Hay et al.) Bukry, 1971. Pl. 2, Figs. 5-9

Discoaster barbadiensis Tan, 1927. Pl. 6, Figs. 2, 3

Discoaster bifax Bukry, 1971. Pl. 5, Fig. 6

Discoaster deflandrei Bramlette and Riedel, 1954

Discoaster diastypus Bramlette and Sullivan, 1961

Discoaster kuepperi Stradner, 1959. Pl. 5, Figs. 16, 17

Discoaster lodoensis Bramlette and Riedel, 1954. Pl. 6, Figs. 4, 5

Discoaster mohleri Bukry and Percival, 1971

Discoaster multiradiatus Bramlette and Riedel, 1954. P1. 6, Fig. 13

Discoaster praebifax Wei and Wise, 1989b

Discoaster saipanensis Bramlette and Riedel, 1954. Pl. 5, Fig. 1

Discoaster sublodoensis Bramlette and Sullivan, 1961

Discoaster tanii Bramlette and Riedel, 1954

Discoaster variabilis Martini and Bramlette, 1963

Ellipsolithus distichus (Bramlette and Sullivan) Sullivan, 1964. Pl. 6, Fig. 16

Ericsonia subpertusa Hay and Mohler, 1967

Fasciculithus pileatus Bukry, 1973

Fasciculithus tympaniformis Hay and Mohler in Hay et al., 1967

Fasciculithus ulii Perch-Nielsen, 1971

Gephyrocapsa oceanica Kamptner, 1943

Helicosphaera compacta Bramlette and Wilcoxon, 1967

Helicosphaera euphratis Haq, 1966

Helicosphaera recta $\mathrm{Haq}, 1966$

Heliolithus kleinpellii Sullivan, 1964. Pl. 6, Figs. 14, 15

Hornibrookina teuriensis Edwards, 1973

Isthmolithus recurvus Deflandre, 1954. Pl. 4, Figs. 9-11

Lanternithus minutus Stradner, 1962

Markalius apertus Perch-Nielsen, 1979

Markalius inversus (Deflandre) Bramlette and Martini, 1964. Pl. 4, Fig. 16

Nannotetrina cristata (Martini) Perch-Nielsen, 1971

Nannotetrina fulgens (Stradner) Achuthan and Stradner, 1969

Neochiastozygus concinnus (Martini) Perch-Nielsen, 1971

Neococcolithes dubius (Deflandre) Black, 1967. Pl. 5, Fig. 15

Pontosphaera multipora (Kamptner) Roth, 1970. Pl. 2, Fig. 3

Prinsius bisulcus (Stradner) Hay and Mohler, 1967

Prinsius dimorphosus (Perch-Nielsen) Perch-Nielsen, 1977

Prinsius martinii (Perch-Nielsen) Haq, 1977

Pseudoemiliania lacunosa (Kamptner) Gartner, 1969

Pyrocyclus orangensis (Bukry) Perch-Nielsen, 1986

Reticulofenestra bisecta (Hay, Mohler, and Wade) Roth, 1970. Pl. 3, Fig. 5; Pl. 4, Fig. 1

Reticulofenestra bisecta filewiczii Wise and Wiegand in Wise, 1983. Pl. 3, Fig. 6; Pl. 4, Fig. 2

Reticulofenestra daviesii (Haq) Haq, 1971. Pl. 4. Fig. 4

Reticulofenestra gelida (Geitzenauer) Backman, 1978. Pl. 1, Figs. 1-4

Reticulofenestra hesslandii (Haq) Roth, 1970. Pl. 2, Figs. 1, 2; PI. 2, Fig. 4

Reticulofenestra oamaruensis (Deflandre) Stradner and Edwards, 1968. Pl. 4, Fig. 12

Reticulofenestra onusta (Perch-Nielsen) Wise, 1983. Pl. 3, Fig. 7

Reticulofenestra perplexa (Burns) Wise, 1983. Pl. 1, Figs 5-10

Reticulofenestra producta Wei and Thierstein, n. com. Pl. 1, Figs. 11, 12

Reticulofenestra pseudoumbilica (Gartner) Gartner, 1969

Reticulofenestra reticulata (Gartner and Smith) Roth and Thierstein, 1972. Pl. 3, Figs. 8, 9; Pl. 5, Figs. 2-4

Reticulofenestra samodurovii (Hay, Mohler, and Wade) Roth, 1970

Reticulofenestra umbilica (Levin) Martini and Ritzkowski, 1968. Pl. 5, Fig. 7

Rhabdosphaera perlongus Deflandre in Grasse, 1952. Pl. 5, Fig. 14

Sphenolithus ciperoensis Bramlette and Wilcoxon, 1967

Sphenolithus moriformis (Bronnimann and Stradner) Bramlette and Wilcoxon, 1967. Pl. 5, Figs. 12, 13 
Sphenolithus radians Deflandre in Grasse, 1952

Toweius callosus Perch-Nielsen, 1971. Pl. 6, Figs. 9, 10

Toweius craticulus Hay and Mohler, 1967

Toweius magnicrassus (Bukry) Romein, 1979. Pl. 6, Figs. 11, 12

Tribrachiatus orthostylus Shamrai, 1963. Pl. 6, Fig. 6

Zygodiscus sigmoides Bramlette and Sullivan, 1961

Zygrhablithus bijugatus (Deflandre) Deflandre, 1959. Pl. 4, Fig. 8

\section{Cretaceous Species}

Ahmuellerella octoradiata (Gorka) Bukry, 1969

Arkhangelskiella cymbiformis Veskshina, 1959

Biscutum constans (Gorka) Black, 1967

Biscutum coronum Wind and Wise in Wise and Wind, 1977

Biscutum magnum Wind and Wise in Wise and Wind, 1977

Broinsonia enormis (Shumenko) Bukry, 1969

Broinsonia parca (Stradner) Bukry, 1969

Broinsonia signata (Noël) Noël, 1970

Chiastozygus litterarius (Gorka) Manivit, 1971

Crepidolithus conicus Bramlette and Martini, 1964

Cretarhabdus surirellus (Deflandre) Reinhardt, 1970

Cribrosphaerella daniae Perch-Nielsen, 1977

Cribrosphaerella ehrenbergii (Arkhangelsky) Deflandre, 1952

Cyclagelosphaera reinhardtii (Perch-Nielsen) Romein, 1977

Cyclageolsphaera margerelii Nol, 1965

Eiffellithus eximius (Stover) Perch-Nielsen, 1968

Eiffellithus trabeculatus (Gorka) Reinhardt and Gorka, 1967

Eiffellithus turriseiffeli (Deflandre) Reinhardt, 1965

Gartnerago nanum Thierstein, 1974

Gartnerago obliquium (Stradner) Nol, 1970

Kamptnerius magnificus Deflandre, 1959

Lithastrinus floralis Stradner, 1962

Lithraphidites carniolensis Deflandre, 1963

Lucianorhabdus cayeuxii Deflandre, 1959

Microrhabdulus decoratus Deflandre, 1959

Micula staurophora (Gardet) Stradner, 1963.

Nephrolithus corystus Wind, 1983

Nephrolithus frequens Gorka, 1957

Parhabdolithus angustus (Stradner) Strandner, Adamiker, and Maresch, 1968

Prediscosphaera cretacea (Arkhangelsky) Gartner, 1968

Prediscosphaera spinosa (Bramlette and Martini) Gartner, 1968

Prediscosphaera stoveri (Perch-Nielsen) Shafik and Stradner, 1971

Reinhardtites anthophorus (Deflandre) Perch-Nielsen, 1968

Reinhardtites levis Prins and Sissing, 1977

Seribiscutum primitivum (Thierstein) Filewicz et al. in Wise and Wind, 1977

Tranolithus orionatus (Reinhardt) Reinhardt, 1966

Watznaueria barnesae (Black) Perch-Nielsen, 1968

Zygodiscus diplogrammus (Delandre) Gartner, 1968

Zygodiscus spiralis Bramlette and Martini, 1964

In alphabetical order of species epithets (plate and figure numbers refer to illustrations in this paper).

\section{Cenozoic Species}

Cyclicargolithus abisectus (Müller) Wise, 1973. Pl. 2, Fig. 10

Chiasmolithus altus Bukry and Percival, 1971. Pl. 2, Fig. 11; Pl. 3, Fig. 4

Markalius apertus Perch-Nielsen, 1979

Discoaster barbadiensis Tan, 1927. Pl. 6, Figs. 2, 3

Chiasmolithus bidens (Bramlette and Sullivan) Hay and Mohler, 1967

Discoaster bifax Bukry, 1971. PI. 5, Fig. 6

Braarudosphaera bigelowii (Gran and Braarud) Deflandre, 1974

Zygrhablithus bijugatus (Deflandre) Deflandre, 1959. PI. 4, Fig. 8

Reticulofenestra bisecta filewiczii Wise and Wiegand in Wise, 1983. Pl.

3, Fig. 6; Pl. 4, Fig. 2

Reticulofenestra bisecta (Hay, Mohler and Wade) Roth, 1970. Pl. 3, Fig.

5; Pl. 4, Fig. 1

Prinsius bisulcus (Stradner) Hay and Mohler, 1967

Toweius callosus Perch-Nielsen, 1971. PI. 6, Figs. 9, 10

Sphenolithus ciperoensis Bramlette and Wilcoxon, 1967

Helicosphaera compacta Bramlette and Wilcoxon, 1967

Neochiastozygus concinnus (Martini) Perch-Nielsen, 1971

Toweius craticulus Hay and Mohler, 1967

Nannotetrina cristata (Martini) Perch-Nielsen, 1971
Chiasmolithus danicus (Brotzen) Hay and Mohler, 1967

Reticulofenestra daviesii (Haq) Haq, 1971. Pl. 4, Fig. 4

Discoaster deflandrei Bramlette and Riedel, 1954

Discoaster diastypus Bramlette and Sullivan, 1961

Prinsius dimorphosus (Perch-Niesen) Perch-Nielsen, 1977

Ellipsolithus distichus (Bramlette and Sullivan) Sullivan, 1964. Pl. 6, Fig. 16

Neococcolithes dubius (Deflandre) Black, 1967. Pl. 5, Fig. 15

Cruciplacolithus edwardsii Romein, 1979

Helicosphaera euphratis Haq, 1966

Chiasmolithus expansus (Bramlette and Sullivan) Gartner, 1970. PI. 5, Fig. 10

Clausicoccus fenestratus (Deflandre and Fert) Prins, 1979. Pl. 4, Figs. 5,6

Cyclicargolithus floridanus (Roth and Hay in Hay et al.) Bukry, 1971. Pl. 2, Figs. 5-9

Coccolithus formosus (Kamptner) Wise, 1973. Pl. 4, Figs. 14, 15

Nannotetrina fulgens (Stradner) Achuthan and Stradner, 1969

Reticulofenestra gelida (Geitzenauer) Backman, 1978. Pl. 1, Figs. 1-4

Chiasmolithus gigas (Bramlette and Sullivan) Radomski, 1968

Chiasmolithus grandis (Bramlette and Sullivan) Radomski, 1978. Pl. 5, Fig. 11

Reticulofenestra hesslandii (Haq) Roth, 1970. Pl. 2, Figs. 1, 2; Pl. 2, Fig. 4

Markalius inversus (Deflandre) Bramlette and Martini, 1964. Pl. 4, Fig. 16

Heliolithus kleinpellii Sullivan, 1964. Pl. 6, Figs. 14, 15

Discoaster kuepperi Stradner, 1959. Pl. 5, Figs. 16, 17

Pseudoemiliania lacunosa (Kamptner) Gartner, 1969

Calcidiscus leptoporus (Murray and Blackman) Loeblich and Tappan, 1978. Pl. 3, Fig. 3

Discoaster lodoensis Bramlette and Riedel, 1954. Pl. 6, Figs. 4, 5

Calcidiscus macintyrei (Bukry and Bramlette) Loeblich and Tappan, 1978. Pl. 3, Figs. 1, 2

Toweius magnicrassus (Bukry) Romein, 1979. Pl. 6, Figs. 11, 12

Prinsius martinii (Perch-Nielsen) Haq, 1977

Lanternithus minutus Stradner, 1962

Discoaster mohleri Bukry and Percival, 1971

Sphenolithus moriformis (Bronnimann and Stradner) Bramlette and Wilcoxon, 1967. Pl. 5, Figs. 12, 13

Pontosphaera multipora (Kamptner) Roth, 1970. Pl. 2, Fig. 3

Discoaster multiradiatus Bramlette and Riedel, 1954. Pl. 6, Fig. 13

Chiasmolithus oamaruensis (Deflandre) Hay, Mohler, and Wade, 1966. Pl. 5, Fig. 9

Reticulofenestra oamaruensis (Deflandre) Stradner and Edwards, 1968. Pl. 4, Fig. 12

Gephyrocapsa oceanica Kamptner, 1943

Reticulofenestra onusta (Perch-Nielsen) Wise, 1983. Pl. 3, Fig. 7

Pyrocyclus orangensis (Bukry) Perch-Nielsen, 1986

Tribrachiatus orthostylus Shamrai, 1963. Pl. 6, Fig. 6

Bicolumnus ovatus Wei and Wise, 1990

Coccolithus pelagicus (Wallich) Schiller, 1930

Rhabdosphaera perlongus Deflandre in Grasse, 1952. P1. 5, Fig. 14

Reticulofenestra perplexa (Burns) Wise, 1983. Pl. 1, Figs. 5-10

Fasciculithus pileatus Bukry, 1973

Discoaster praebifax Wei and Wise, 1989b

Cruciplacolithus primus Perch-Nielsen, 1977

Reticulofenestra producta Wei and Thierstein, n. com. Pl. 1, Figs. 11, 12

Reticulofenestra pseudoumbilica (Gartner) Gartner, 1969

Sphenolithus radians Deflandre in Grasse, 1952

Helicosphaera recta Haq, 1966

Isthmolithus recurvus Deflandre, 1954. Pl. 4, Figs. 9-11

Reticulofenestra reticulata (Gartner and Smith) Roth and Thierstein, 1972. Pl. 3, Figs. 8, 9; Pl. 5, Figs. 2-4

Discoaster saipanensis Bramlette and Riedel, 1954. Pl. 5, Fig. 1

Reticulofenestra samodurovii (Hay, Mohler, and Wade) Roth, 1970

Zygodiscus sigmoides Bramlette and Sullivan, 1961

Chiasmolithus solitus (Bramlette and Sullivan) Locker, 1968

Biantholithus sparsus Bramlette and Martini, 1964

Blackites spinosus (Deflandre and Fert) Hay and Towe, 1962

Discoaster sublodoensis Bramlette and Sullivan, 1961

Ericsonia subpertusa Hay and Mohler, 1967

Discoaster tanii Bramlette and Riedel, 1954

Cruciplacolithus tenuis (Stradner) Hay and Mohler in Hay et al., 1967 
Hornibrookina teuriensis Edwards, 1973

Fasciculithus ulii Perch-Nielsen, 1971

Reticulofenestra umbilica (Levin) Martini and Ritzkowski, 1968. Pl. 5, Fig. 7

Discoaster variabilis Martini and Bramlette, 1963

Fasciculithus tympaniformis Hay and Mohler in Hay et al., 1967

\section{Cretaceous Species}

Parhabdolithus angustus (Stradner) Strandner, Adamiker, and Maresch, 1968

Reinhardtites anthophorus (Deflandre) Perch-Nielsen, 1968

Watznaueria barnesae (Black) Perch-Nielsen, 1968

Lithraphidites carniolensis Deflandre, 1963

Lucianorhabdus cayeuxii Deflandre, 1959

Crepidolithus conicus Bramlette and Martini, 1964

Biscutum constans (Gorka) Black, 1967

Biscutum coronum Wind and Wise in Wise and Wind, 1977

Nephrolithus corystus Wind, 1983

Prediscosphaera cretacea (Arkhangelsky) Gartner, 1968

Arkhangelskiella cymbiformis Veskshina, 1959

Cribrosphaerella daniae Perch-Nielsen, 1977

Microrhabdulus decoratus Deflandre, 1959

Zygodiscus diplogrammus (Delandre) Gartner, 1968

Cribrosphaerella ehrenbergii (Arkhangelsky) Deflandre, 1952
Broinsonia enormis (Shumenko) Bukry, 1969

Eiffellithus eximius (Stover) Perch-Nielsen, 1968

Lithastrinus floralis Stradner, 1962

Nephrolithus frequens Gorka, 1957

Reinhardtites levis Prins and Sissing, 1977

Chiastozygus litterarius (Gorka) Manivit, 1971

Kamptnerius magnificus Deflandre, 1959

Biscutum magnum Wind and Wise in Wise and Wind, 1977

Cyclagelosphaera margerelii Noël, 1965

Gartnerago nanum Thierstein, 1974

Gartnerago obliquium (Stradner) Noël, 1970

Seribiscutum primitivum (Thierstein) Filewicz et al. in Wise and Wind, 1977

Ahmuellerella octoradiata (Gorka) Bukry, 1964

Tranolithus orionatus (Reinhardt) Reinhardt, 1966

Broinsonia parca (Stradner) Bukry, 1969

Cyclagelosphaera reinhardtii (Perch-Nielsen) Romein, 1977

Broinsonia signata (Noël) Noël, 1970

Prediscosphaera spinosa (Bramlette and Martini) Gartner, 1968

Zygodiscus spiralis Bramlette and Martini, 1964

Micula staurophora (Gardet) Stradner, 1963.

Prediscophaera stoveri (Perch-Nielsen) Shafik and Stradner, 1971

Cretarhabdus surirellus (Deflandre) Reinhardt, 1970

Eiffellithus trabeculatus (Gorka) Reinhardt and Gorka, 1967

Eiffellithus turriseiffeli (Deflandre) Reinhardt, 1965 

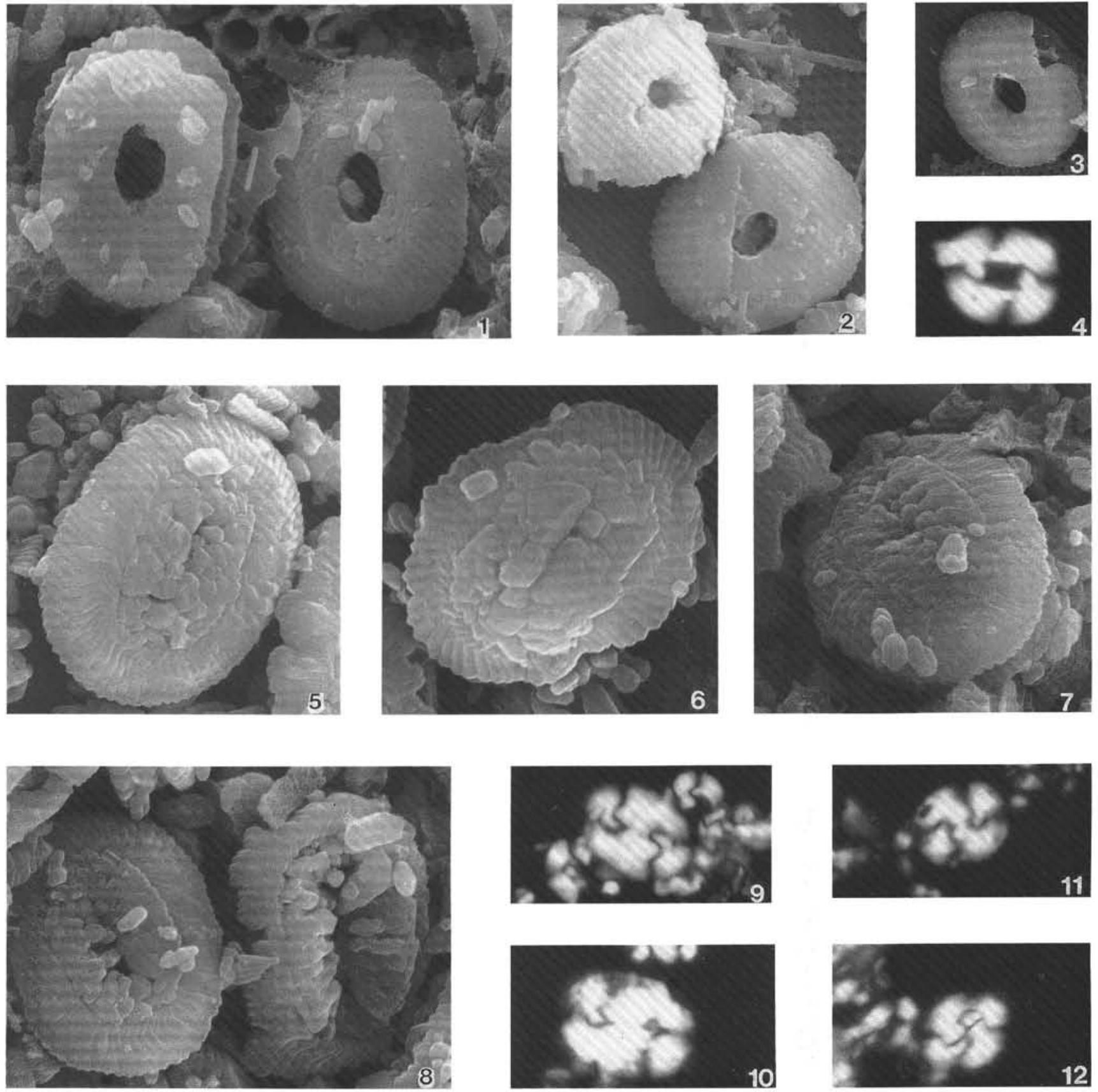

Plate 1. 1-4. Reticulofenestra gelida (Geitzenauer) Backman, Sample 119-737B-5R-3, 45-47 cm; (1) proximal view on left and distal view on right,

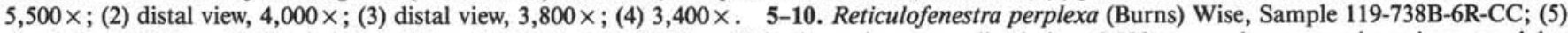
distal view, $6,000 \times$; (6) distal view, $8,000 \times$; (7) distal view, $6,000 \times ;(8)$ both specimens are distal view, $6,500 \times$, poorly preserved specimen on right; $(9,10) 3,200 \times$. 11, 12. Reticulofenestra producta (Kamptner) Wei and Thierstein, 3,400×, Sample 119-737B-5R-3, 45-47 cm. 

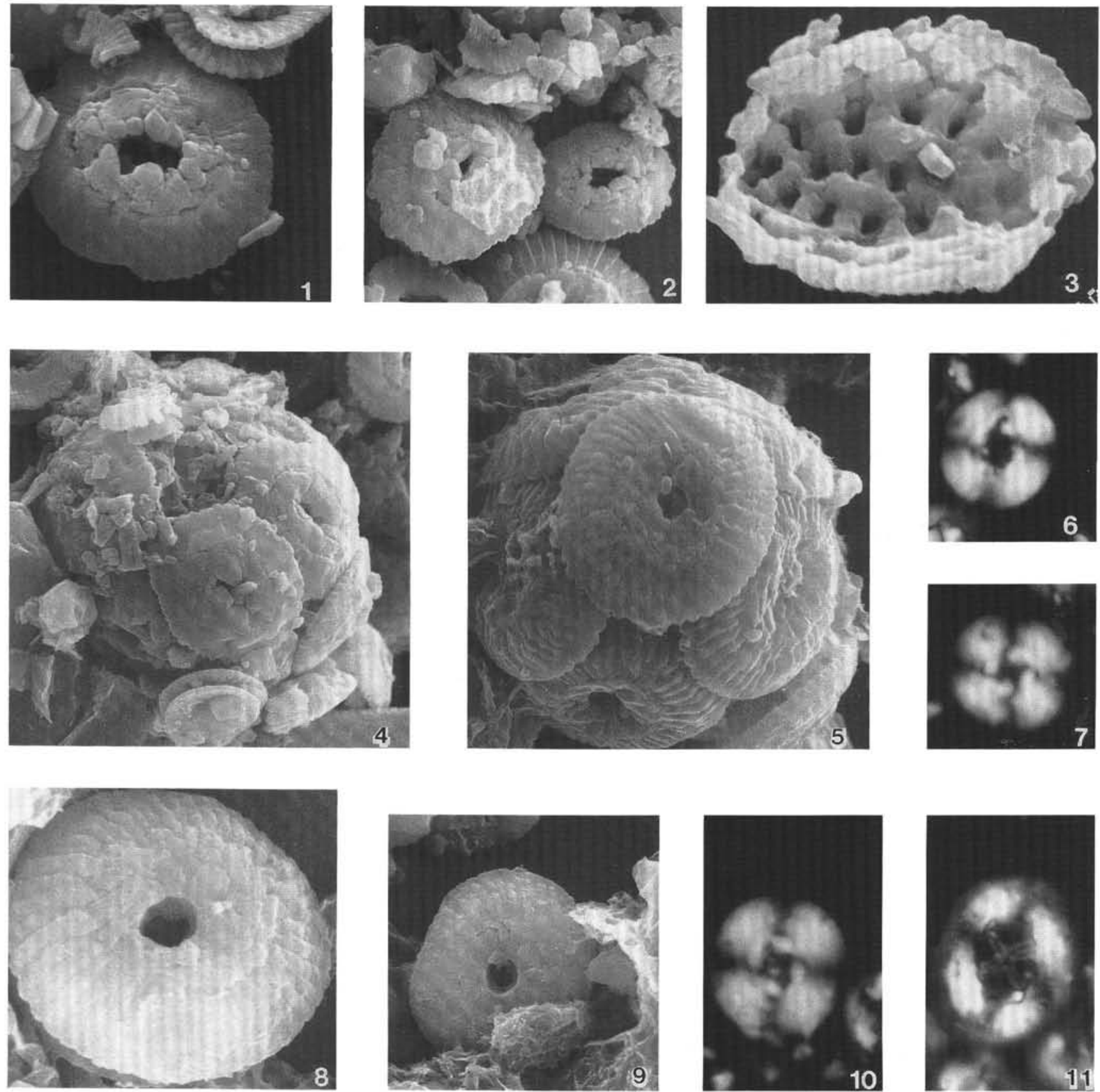

Plate 2. 1, 2. Reticulofenestra hesslandii (Haq) Roth, Sample 119-737B-10R-3, 45-47 cm; (1) distal view, 5,500 × (2) both specimens are distal view, note variation in size, 4,000×. 3. Pontosphaera multipora (Kamptner) Roth, 9,000×, Sample 119-737B-17R-4, 36-38 cm. 4. Coccosphere of Reticulofenestra hesslandii (Haq) Roth, 3,500×, Sample 119-737B-10R-3, 45-47 cm. 5-9. Cyclicargolithus floridanus (Roth and Hay) Bukry; (5) coccosphere, 5,000×, Sample 119-737B-12R-5, 30-31 cm; (6, 7) 2,700 $\times$, Sample 119-744A-8H-1, 75-76 cm; (8)'distal view, 7,000 $\times$, Sample 119-737B13R-1, 43-44 cm; (9) distal view, 4,300 $\times$, Sample 119-737B-12R-5, 30-31 cm. 10. Cyclicargolithus abisectus (Müller) Wise, 2,700 $\times$, Sample 119-737B15R-1, 45-47 cm. 11. Chiasmolithus altus Bukry and Percival, 2,700 $\times$, Sample 119-737B-15R-1, 45-46 cm. 

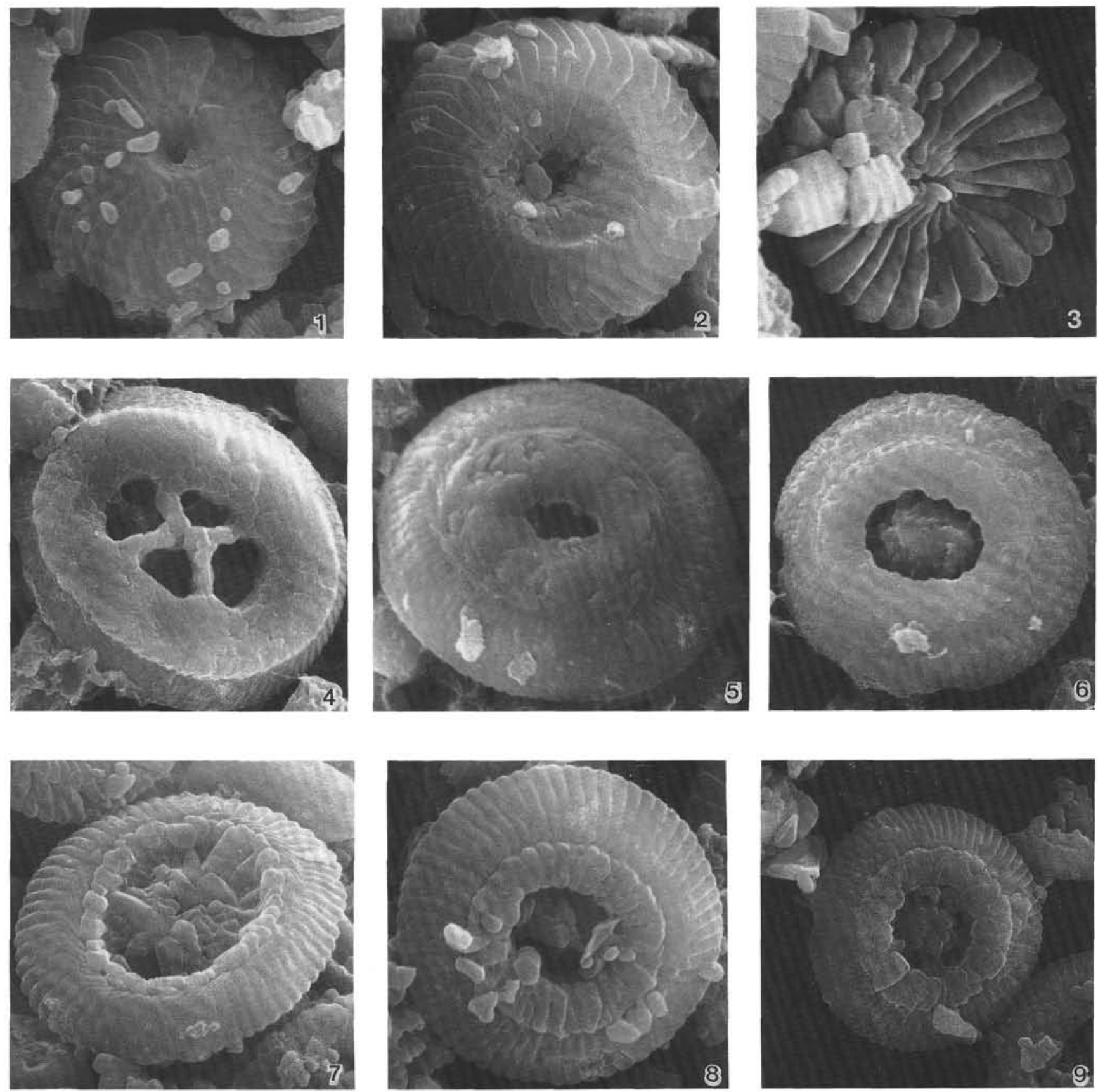

Plate 3. 1, 2. Calcidiscus macintyrei (Bukry and Bramlette) Loeblich and Tappan; (1) distal view, 5,500 $\times$, Sample 119-744B-7H-1, 110-111 cm; (2) distal view, 6,500 $\times$, Sample 119-744B-8H-6, $110-111 \mathrm{~cm}$. 3. Calcidiscus leptoporus (Murray and Blackman) Loeblich and Tappan, proximal view, $7,500 \times$, Sample 119-744B-8H-6, 110-111 cm. 4. Chiasmolithus altus Bukry and Percival, distal view, 4,300 $\times$, Sample 119-737B-12R-5, 30-31 $\mathrm{cm}$. 5. Reticulofenestra bisecta (Hay, Mohler, and Wade) Roth, distal view, 4,300×, Sample 119-737B-12R-5, 30-31 cm. 6. Reticulofenestra bisecta filewiczii Wise and Wiegand, distal view, 5,500×, Sample 119-737B-12R-5, 30-31 cm. 7. Reticulofenestra onusta (Perch-Nielsen) Wise, distal view, note the wide and flat central area, 7,500 $\times$, Sample 119-738B-17X-1, 66-68 cm. 8, 9. Reticulofenestra reticulata (Gartner) Roth; (8) distal view, 6,500 , Sample 119-744A-20H-6, 75-76 cm; (9) distal view, 4,300×, Sample 119-738B-5H-7, 60-62 cm. 

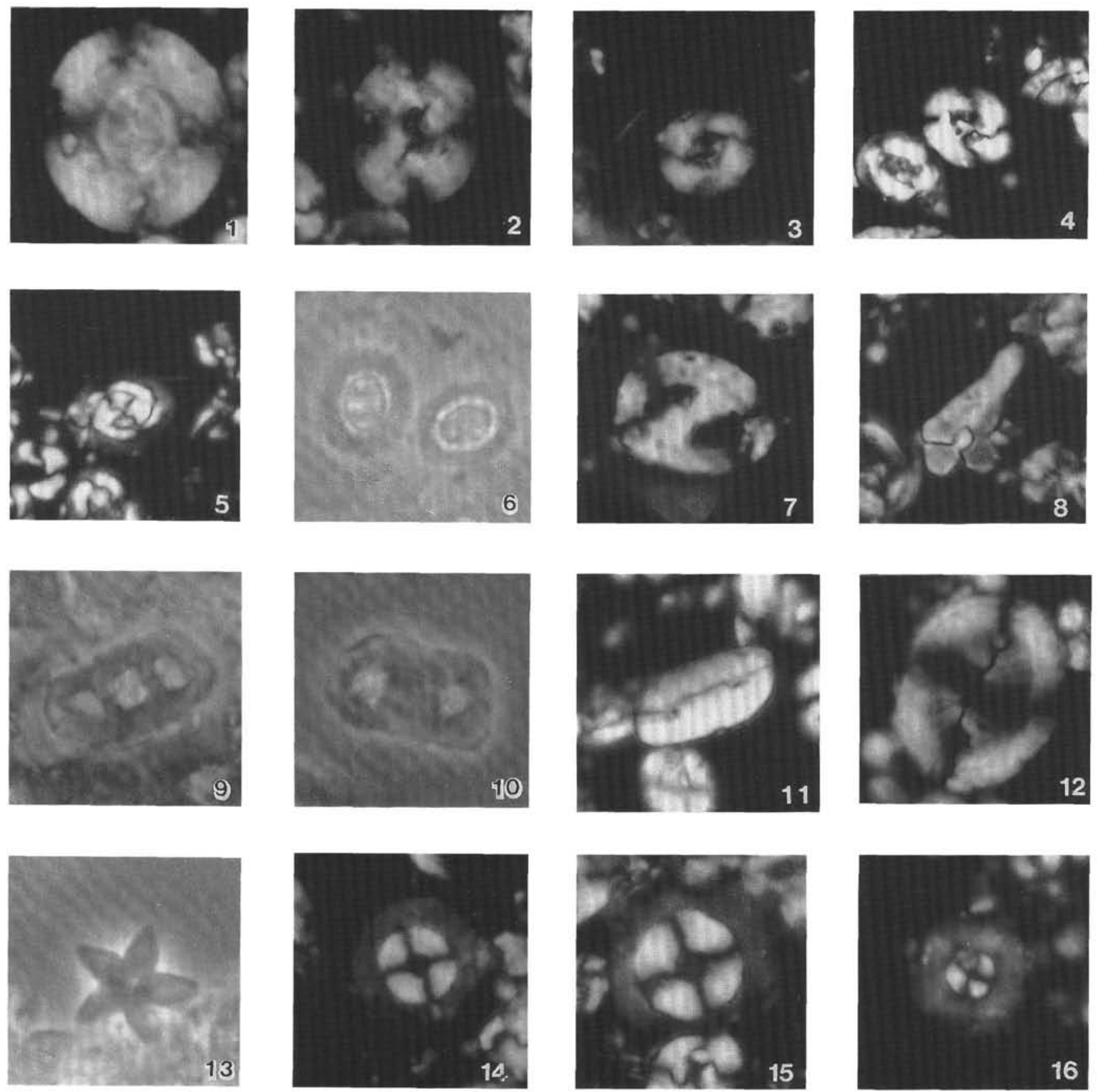

Plate 4. 1. Reticulofenestra bisecta (Hay, Mohler, and Wade) Roth, 2,700 $\times$, Sample 119-744A-13H-6, 25-26 cm. 2. Reticulofenestra bisecta filewiczii Wise and Wiegand, 2,700×, Sample 119-744A-13H-6, 25-26 cm. 3, 4. Reticulofenestra daviesii (Haq) Haq, 2,700 $\times$, Sample 119-737B-39R5, 28-29 cm. 5, 6. Clausicoccus fenestratus (Deflandre and Fert) Prins, 2,700 $\times$, Sample 119-744A-15H-CC. 7. Transversopontis sp. 2,700 Sample 119-737B-43R-1, 62-64 cm. 8. Zygrhablithus bijugatus (Deflandre) Deflandre, 2,700 $\times$, Sample 119-738C-24X-CC. 9-11. Isthmolithus recurvus Deflandre, 3,200×, note variation in overgrowth; $(9,10)$ Sample $119-737 \mathrm{~B}-38 \mathrm{R}-3,27-28 \mathrm{~cm} ;(11)$ Sample $119-744 \mathrm{~A}-16 \mathrm{H}-1,75-76 \mathrm{~cm}$. 12. Reticulofenestra oamaruensis (Deflandre) Stradner and Edwards, 2,300×, Sample 119-744A-18H-4, 75-76 cm. 13. Discoaster sp., 2,700 $\times$, Sample 119-738B-4H-5, 66-68 cm. 14, 15. Coccolithus formosus (Kamptner) Wise, 3,500 $\times$, Sample 119-737B-39R-3, 86-87 cm. 16. Markalius inversus (Deflandre) Bramlette and Martini, 2,700×, Sample 119-744A-20H-1, 75-76 cm. 

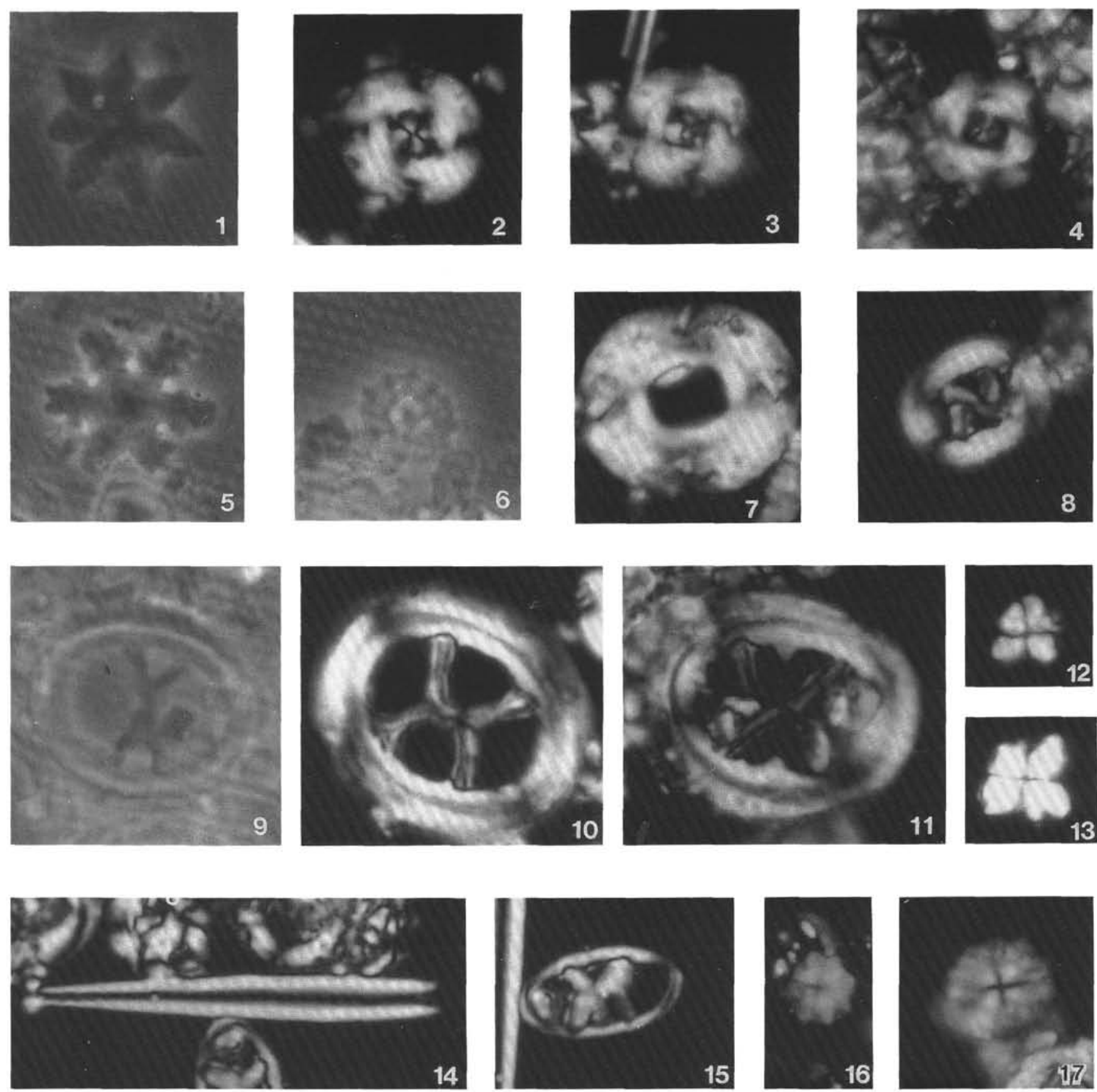

Plate 5. 1. Discoaster saipanensis Bramlette and Riedel, 2,300×, Sample 119-744A-19H-5, 75-76 cm. 2-4. Reticulofenestra reticulata (Gartner) Roth, 2,300×, Sample 119-744A-20H-4, 75-76 cm. 5. Discoaster sp., 2,300×, Sample 119-737B-48R-2, 22-23 cm. 6. Discoaster bifax Bukry, 2,100×, Sample 119-737B-52R-CC. 7. Reticulofenestra umbilica (Levin) Martini and Ritzkowski, 2,300×, Sample 119-738B-12H-3, 66-68 cm. 8. Chiasmolithus solitus (Bramlette and Sullivan) Locker, $2,700 \times$. 9. Chiasmolithus oamaruensis (Deflandre) Hay, Mohler, and Wade, 2,700 $\times$, Sample 119-744A-16H-1, 75-76 cm. 10. Chiasmolithus expansus (Bramlette and Sullivan) Gartner, 2,100×, Sample 119-738B-15X-4, 66-68 cm. 11. Chiasmolithus grandis (Bramlette and Riedel) Gartner, 2,700 $\times$, Sample 119-738B-23X-CC. 12, 13. Sphenolithus moriformis (Brönnimann and Stradner) Bramlette and Wilcoxon, 2,300 × , Sample 119-738B-5H-7, 60-62 cm. 14. Rhabdosphaera perlongus Deflandre, 2,700 $\times$, Sample 119738B-21X-2, 66-68 cm. 15. Neococcolithes dubius (Deflandre) Black, 2,700×, Sample 119-738B-21X-2, 66-68 cm. 16, 17. Discoaster kuepperi Stradner, Sample 119-738C-6R-1, 66-67 cm. (16) 2,100× (17) 2,700× . 

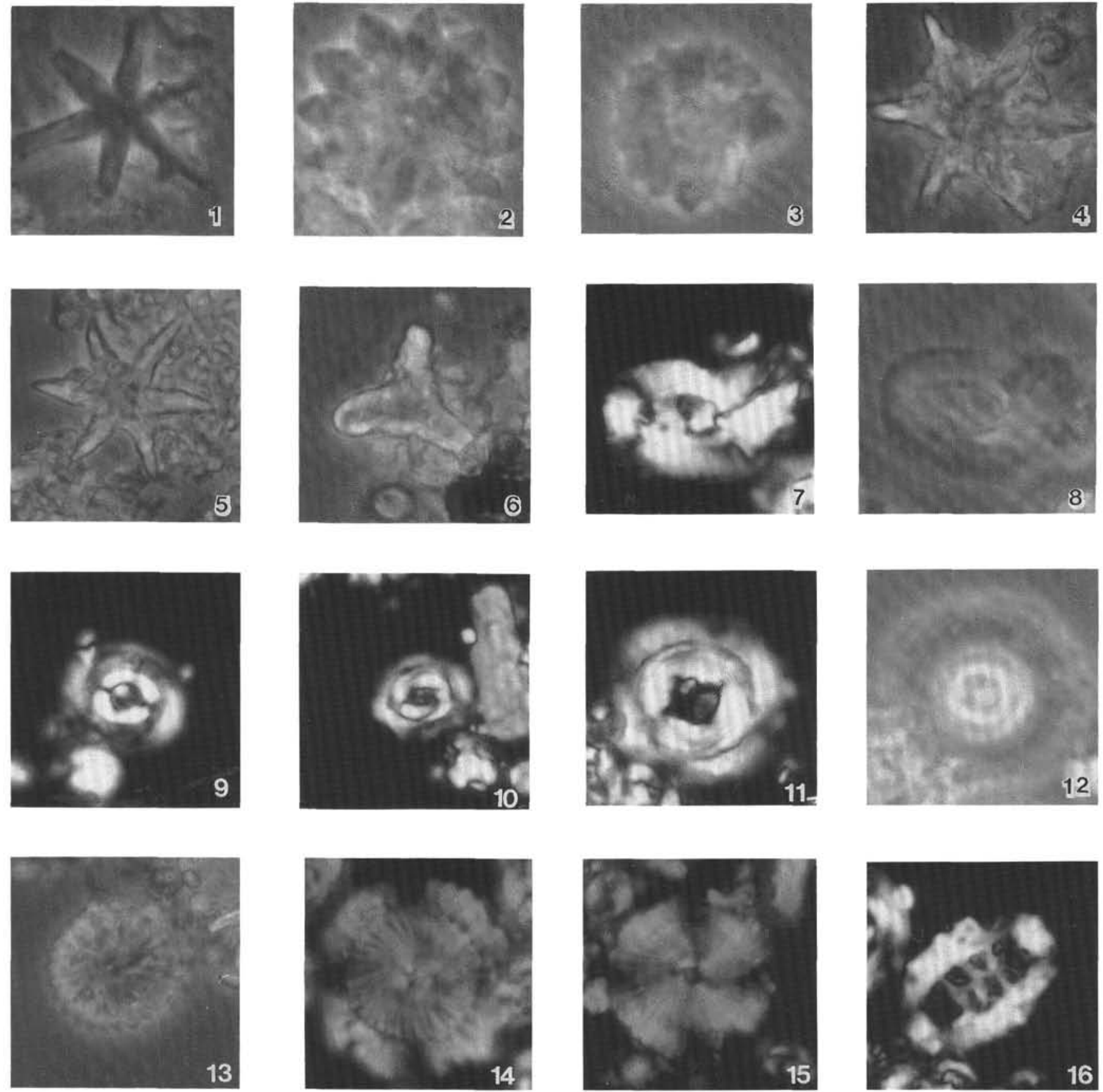

Plate 6. 1. Discoaster sp. 2,700×, Sample 119-737B-46R-1, 1-2 cm. 2, 3. Discoaster barbadiensis Tan, Sample 119-737B-52R-CC; (2) 2,700 $\times$; (3) $2,500 \times$. 4, 5. Discoaster lodoensis Bramlette and Riedel, $1,900 \times$, Sample 119-738C-5R-1, 69-70 cm. 6. Tribrachiatus orthostylus Shamrai, 2,700× Sample 119-738C-10R-1, 66-68 cm. 7, 8. Helicosphaera sp., 2,300×, Sample 119-738B-10H-2, 66-68 cm. 9, 10. Toweius callosus PerchNielsen, 2,300×; (9) Sample 119-738C-5R-2, 69-70 cm; (10) Sample 119-738C-11R-1, 90-91 cm. 11, 12. Toweius magnicrassus (Bukry) Romein, 2,300 $\times$, Sample 119-738B-24X-3, 66-67 cm. 13. Discoaster multiradiatus Bramlette and Riedel, 1,400 $\times$, Sample 119-738C-11R-11, 90-91 cm. 14-15. Heliolithus kleinpellii Sullivan, 2,300×, Sample 119-738C-15R-CC. 16. Ellipsolithus distichus (Bramlette and Sullivan, 2,700 $\times$, Sample $119-738 \mathrm{C}-2 \mathrm{R}-2,22-23 \mathrm{~cm}$. 